\title{
Temperature effects on respiration and photosynthesis in three diatom-dominated benthic communities
}

\author{
Kasper Hancke $^{1,2, *}$, Ronnie N. Glud ${ }^{1}$ \\ ${ }^{1}$ Marine Biological Laboratory, University of Copenhagen, Strandpromenaden 5, 3000 Helsingør, Denmark \\ ${ }^{2}$ Present address: Trondhjem Biological Station, Norwegian University of Science and Technology, 7491 Trondheim, Norway
}

\begin{abstract}
Short-term temperature effects on respiration and photosynthesis were investigated in intact diatom-dominated benthic communities, collected at 2 temperate and 1 high-arctic subtidal sites. Areal rates of total (TOE) and diffusive (DOE) $\mathrm{O}_{2}$ exchange were determined from $\mathrm{O}_{2}$-microsensor measurements in intact sediment cores in the temperature range from 0 to $24^{\circ} \mathrm{C}$ in darkness and at $140 \mu \mathrm{mol}$ photons $\mathrm{m}^{-2} \mathrm{~s}^{-1}$. In darkness, the $\mathrm{O}_{2}$ consumption increased exponentially with increasing temperature for both TOE and DOE, and no optimum temperature was observed within the applied temperature range. $Q_{10}$ was calculated from the linear slope in Arrhenius plots and ranged between 1.7 and 3.3 at the respective sites. The volume-specific rate $\left(R_{\text {dark,vol }}\right)$ solely representing the biological temperature response was somewhat stronger, with $Q_{10}$ values of 2.6 to 5.2. The $Q_{10}$ values were overall not correlated to the in situ water temperature or geographical position. Accordingly, no difference in the temperature acclimation or adaptation strategy of the microbial community was observed. Slurred oxic sediment samples showed a $Q_{10}$ of 1.7 and were, hence, lower than estimates based on intact sediment core measurements. This can be ascribed to changes in physical and biological controls during resuspension. Gross photosynthesis was measured with the light-dark shift method at the 2 temperate sites. Both areal $\left(P_{\text {gross }}\right)$ and volumetric $\left(P_{\text {gross,vol }}\right)$ rates increased with temperature to an optimum temperature at 12 and $15^{\circ} \mathrm{C}$, with a $Q_{10}$ for $P_{\text {gross }}$ of 2.2 and 2.6 for the 2 sites, respectively. The gross photosynthesis response could be categorised as psychrotrophic for both sites and no temperature adaptation was observed between the 2 sites. Our measurements document that temperature stimulates heterotrophic activity more than gross photosynthesis, and that the benthic communities gradually become heterotrophic with increasing temperature. This has implications for $\mathrm{C}$-cycling in shallow water communities experiencing seasonal and diel temperature fluctuations.
\end{abstract}

KEY WORDS: Temperature $\cdot$ Adaptation $\cdot$ Benthic microphytes $\cdot$ Photosynthesis $\cdot$ Respiration $\cdot Q_{10} \cdot$ Microelectrodes · Oxygen

\section{INTRODUCTION}

Temperature and irradiance are important environmental controls on photosynthesis and respiration in marine sediments (e.g. Hartwig 1978, Rasmussen et al. 1983, Grant 1986, MacIntyre \& Cullen 1995). In shallow waters, both variables change on a seasonal and a diel basis superimposed by tidal and weather-driven variations, all having an impact on the benthic micro- bial activity (Grant 1986, Cahoon 1999, Glud et al. 2002). Studies at subtidal and intertidal sites have shown that temperature can exert tight control on benthic photosynthetic rates, and can lead to seasonal acclimation and/or change in the microphytobenthic community composition (Rasmussen et al. 1983, Grant 1986, Blanchard et al. 1996, Barranguet et al. 1998). Temperature acclimation usually describes phenotypic changes in a community as a response to short-term 
temperature change, whereas temperature adaptation involves genetic differences in metabolism between communities from different thermal environments (Berry \& Bjorkman 1980, Davison 1991). Temperature adaptation in microorganisms has typically been studied in cultures or in sediment slurries placed in benches at well-defined temperatures (Blanchard et al. 1996, Isaksen \& Jørgensen 1996, Thamdrup \& Fleischer 1998). Based on data for minimum, optimum and maximum temperatures of the activity, the organisms are divided into groups, such as psychrophile, mesophile and thermophile, that tolerate low, medium and high temperatures, respectively (Davison 1991).

Temperature-changed activity is often quantified by the so-called $Q_{10}$ factor (the relative rate of increase at a temperature increase of $10^{\circ} \mathrm{C}$ ). Such studies have shown an insignificant difference in temperature adaptation of aerobic respiration between arctic and temperate communities (Thamdrup \& Fleischer 1998). In contrast, lower $Q_{10}$ values have been reported for benthic sulphate reduction in Antarctic sediments compared to measurements performed at temperate latitudes (Isaksen \& Jørgensen 1996). However, most benthic temperature studies have been performed on highly manipulated samples or inferred from seasonal rates at in situ temperature, which may be confounded by changes in other environmental controls. To our knowledge, only 2 detailed temperature studies on
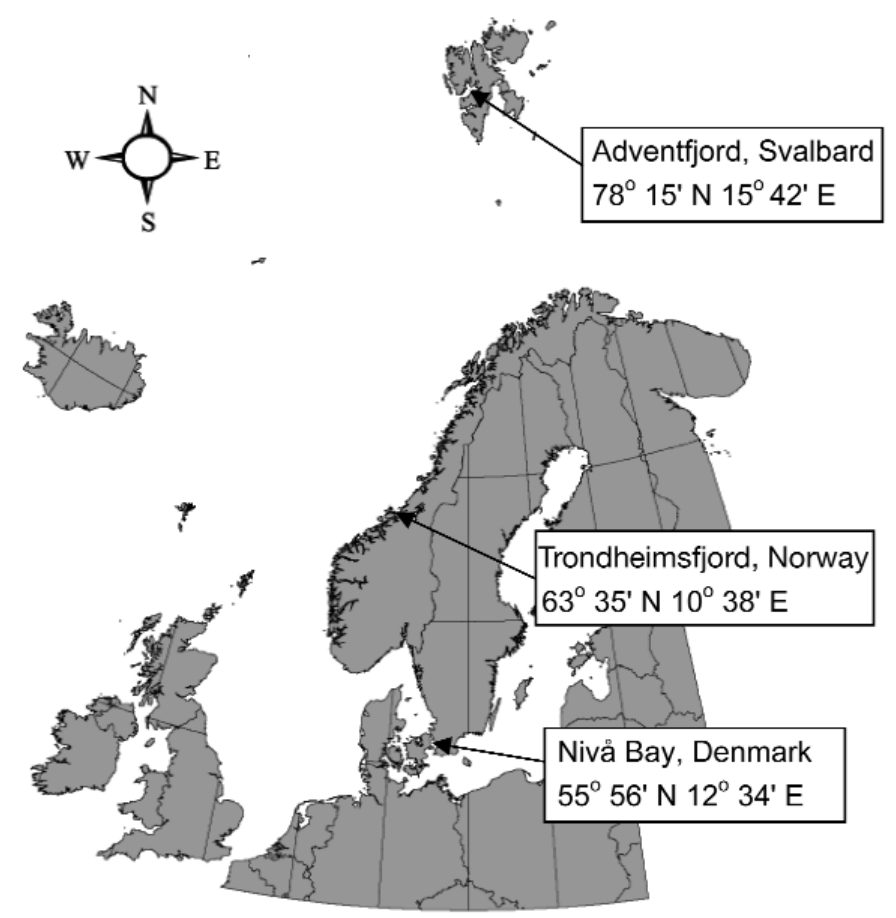

Fig. 1. Map including the sampling sites, Nivå Bay, Denmark, the Trondheimsfjord, Norway, and the Adventfjord, Svalbard, Norway intact benthic communities exist, both performed in hyper-saline mat systems (Epping \& Kühl 2000, Wieland \& Kühl 2000). No detailed studies have been performed on subtidal microphytic communities.

Studying the temperature response of intact benthic microbial communities is complicated by the simultaneous impact on physical and chemical controls, and by the fact that benthic microbial communities host a complex phototrophic and heterotrophic diversity (Revsbech et al. 1981, Epping \& Jørgensen 1996, Fenchel \& Glud 2000). Temperature studies of aerobic activity based on traditional bell jar approaches can easily be misinterpreted, as they do not account for changes in $\mathrm{O}_{2}$ penetration depth (Epping \& Jørgensen 1996). Further, it is to be expected that data from slurry samples can be biased due to changes in the benthic community structure and in the environmental controls. Application of $\mathrm{O}_{2}$ microsensors allows a detailed and unconfounded evaluation of the biological temperature effects on both photosynthesis and respiration with a high spatial resolution (Revsbech \& Jørgensen 1986, Glud et al. 2000).

The aim of the present study was to evaluate possible differences in the temperature adaptation strategy between arctic and temperate benthic microphyte communities, during short-term temperature variations. The study includes rate measurements of sediment community respiration, gross photosynthesis and net photosynthesis as determined from $\mathrm{O}_{2}$ microsensor measurements in intact sediments, sampled at 3 different sites.

\section{MATERIALS AND METHODS}

Study site and conditions. Sediment samples were collected from a temperate site (Nivå Bay, Denmark), a northern-temperate site (Trondheimsfjord, Norway) and a high-arctic site (Adventfjord, Svalbard, Norway) (Fig. 1). The 3 sites were located in the subtidal zone (water depth $<4 \mathrm{~m}$, Table 1) and characterised by finegrained sandy sediments, without onsite-growing macroalgae or vascular plants. Median grain size was not determined but microscopic investigations suggested that the mean grain size was around 200 to $500 \mu \mathrm{m}$ at all the investigated sites. All sites were located in partly protected semi-enclosed bays, and the benthic microphytes were apparent as a goldenbrownish colouring of the sediment surface. Microscopic analyses of fresh and Lugol-fixed samples verified that the benthic microphytes were dominated by the pennate diatom genera Nitzschia and Navicula. Few specimens of Fragilaria, Surirella and Amphora were observed. There was no apparent difference in the genera present at the different sites. 
Table 1. Time of sampling, geographical position, and in situ water temperature, irradiance, salinity, water depth, and chlorophyll a concentration for the 3 investigated sites. n: number of samples

\begin{tabular}{|c|c|c|c|}
\hline Parameter/site & $\begin{array}{l}\text { Nivå Bay } \\
\text { (Denmark) }\end{array}$ & $\begin{array}{l}\text { Trondheimsfjord } \\
\text { (Norway) }\end{array}$ & $\begin{array}{c}\text { Adventfjord } \\
\text { (Svalbard, Norway) }\end{array}$ \\
\hline Time of sampling & February 2001 & March 2002 & May $2000^{\mathrm{d}}$ \\
\hline Temperature $\left({ }^{\circ} \mathrm{C}\right)^{\mathrm{a}}$ & $2.5 \pm 1.3(0-30)$ & $4.2 \pm 0.7(0-18)$ & $-1.6 \pm 0.2(-1.8-7.0)$ \\
\hline Irradiance $\left(\mu \mathrm{mol} \text { photons } \mathrm{m}^{-2} \mathrm{~s}^{-1}\right)^{\mathrm{b}}$ & $68 \pm 46(380)$ & $35 \pm 20(83)$ & $46 \pm 35$ (195) \\
\hline Salinity $(\% o)^{\mathrm{c}}$ & $18 \pm 7$ & $29 \pm 3$ & $34 \pm 0.4$ \\
\hline Water depth (m) & $0.4 \pm 0.2$ & $3.0 \pm 1.5$ & $1.3 \pm 0.6$ \\
\hline Chlorophyll a $\left(\mathrm{mg} \mathrm{m}^{-2}\right)$ & $22.9 \pm 6.5(n=4)$ & $23.8 \pm 5.6(\mathrm{n}=10)$ & $2.7 \pm 0.7(\mathrm{n}=4)$ \\
\hline \multicolumn{4}{|c|}{$\begin{array}{l}\text { an situ temperature at day of sampling, annual temperature range shown in parentheses } \\
\text { b Average incident irradiance (during light hours) measured on sediment surface at day of sampling; maximum measured } \\
\text { irradiance at month of sampling shown in parentheses } \\
\text { 'Measured across a } 30 \mathrm{~d} \text { interval } \\
{ }^{\mathrm{d} S} \text { Sampled beneath } 40 \text { to } 50 \mathrm{~cm} \text { of sea ice cover }\end{array}$} \\
\hline
\end{tabular}

Sediment porosity $(\phi)$ was determined by core slicing and subsequent drying, but resulted in underestimated values due to an unavoidable loss of water in the relatively sandy sediment (data not shown). Therefore, porosity was instead estimated from the ratio between the $\mathrm{O}_{2}$ concentration gradient measured immediately above and below the sediment surface (Glud et al. 1995, Epping \& Jørgensen 1996). In addition, porosity was estimated from resistivity measurements according to Klinkenberg (1951) and Ullman \& Aller (1982). The average porosity applying these 2 approaches amounted to $0.60 \pm 0.11(n=19)$. No significant difference in porosity was observed between the investigated sites and the same value was therefore used for all calculations.

All samples were collected during the winter months and consequently the temperature at the time of sampling was close to the minimum of the annual range (Table 1). Irradiance and salinity during the sampling periods are shown in Table 1. Incident irradiance and temperature at the sediment surface were measured using small-submerged data loggers (HOBO, Onset Computer Cooperation), intercalibrated to a cosinecorrected quantum sensor (LiCor LI-190SA connected to a LiCor LI-1000 data logger). The chlorophyll a (chl a) concentration of the surficial sediment $(0$ to $1 \mathrm{~cm}$ ) was determined from at least 4 sediment cores at each site. Samples were initially frozen at $-80^{\circ} \mathrm{C}$ and subsequently extracted in $96 \%$ ethanol for $24 \mathrm{~h}$. The chl a concentration was determined spectrophotometrically (Parsons \& Strickland 1963) using the extinction coefficient suggested by Wintermans \& DeMots (1965) (Table 1).

Sampling and experimental set-up. Samples were collected by hand in Nivå Bay, by SCUBA divers in the Trondheimsfjord, and by a 'kayak'-like home-made sampler in the Adventfjord. During sampling in the Adventfjord 40 to $50 \mathrm{~cm}$ of sea ice covered the fjord and holes were drilled prior to sampling. All samples were collected directly in Plexiglas core liners (inner diameter $=52 \mathrm{~mm}$; length $\approx 150 \mathrm{~mm}$ ). Intact, undisturbed sediment cores with clear overlying water and without larger stones were selected. For each site, 6 to 12 cores were sampled, placed in an insulated box and transported within a couple of hours and with minimum disturbance to the laboratory. In the laboratory, cores were placed in bottom water from the sampling site kept at in situ temperature. The cores were exposed to a 12:12 h light:dark cycle (140:0 $\mu \mathrm{mol}$ photons $\mathrm{m}^{-2} \mathrm{~s}^{-1}$, respectively) by a halogen lamp (Schott KL 1500). Even though the daylight period was longer at the more northern sites, irradiance at the 3 sites was comparable as a consequence of lower zenith angle of the sun at higher latitude. Data from the Trondheimsfjord were based on 3 individual sampling sessions, whereas data from Nivå Bay and the Adventfjord were based on a single set of samples from each site.

To enable temperature manipulation of the sediment cores, a microcosm was constructed (Fig. 2). By combinating a heating plate and a cooling coil, water temperature in the microcosms was changed in steps of $3 \pm$ $0.2^{\circ} \mathrm{C}$. A halogen lamp equipped with an optical fiber served as light source (Schott KL 1500) and incident irradiance was measured at the sediment surface using a cosine-corrected quantum sensor (LiCor LI-190SA). A stable water flow above the sediment surface was secured using an internal rotating magnet, which caused a diffusive boundary layer (DBL) of 300 to $500 \mu \mathrm{m}$ at the measuring spots. Flushing by an air pump kept the water of the microcosm at atmospheric oxygen saturation at all times.

Microsensor measurements. All oxygen measurements were carried out using Clark-type $\mathrm{O}_{2}$ microelectrodes with a guard cathode (Revsbech 1989). Total oxygen exchange (TOE) rates were measured using electrodes with external tip diameters of $\sim 1000 \mu \mathrm{m}$, 


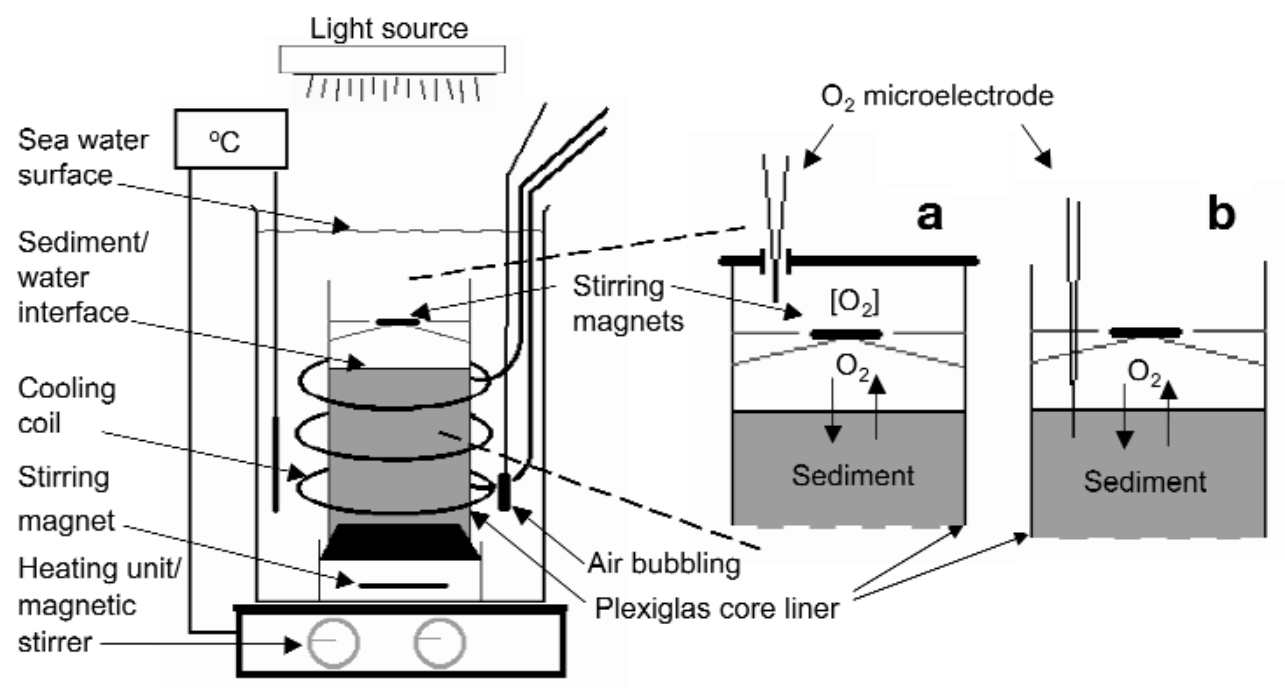

Fig. 2. Microcosms in which samples were installed prior to and during measurements. Sample temperature was controlled by a cooling coil and a heating plate connected to a digital temperature sensor. Two Teflon-coated magnets were installed and driven by a magnetic stirrer in the heating plate (65 to $70 \mathrm{rpm})$. The upper magnet (20 mm length) was mounted inside the core liner, $30 \mathrm{~mm}$ above the sediment surface, by a thin metal wire. The lower magnet provided stirring of the water in the microcosm, together with the air bubbling. (a) Close-up of the upper sediment core closed by a transparent lid mounted with an $\mathrm{O}_{2}$ microelectrode and stirring magnet. (b) Close-up of the upper sediment core open to the surrounding water, with a positioned $\mathrm{O}_{2}$ microelectrode for measuring $\mathrm{O}_{2}$ microprofiles

stirring sensitivity of $<3 \%$, and a $90 \%$ response time of $<40$ s (Glud et al. 2000). Gross photosynthesis and microprofiles were measured using electrodes with external tip diameters $<15 \mu \mathrm{m}$, stirring sensitivity $<1 \%$ and a $90 \%$ response time $<0.5 \mathrm{~s}$. All electrodes were calibrated at the individual temperature settings by a 2point calibration performed in both anoxic and airsaturated samples (Glud et al. 2000). This is essential because the Clark-type microelectrode responds to the partial pressure of $\mathrm{O}_{2}$, thus the signal is sensitive to ambient temperature (Gundersen et al. 1998). The sensors were positioned either manually or by motor-driven micromanipulators. The sensor current was measured using a picoammeter (Unisense) connected to a strip chart recorder and a PC using the software 'Profix' (Unisense) (Revsbech \& Jørgensen 1986).

Total oxygen exchange measurements. TOE rates were calculated from the change in the $\mathrm{O}_{2}$ concentration of the overlying water, accounting for the enclosed water volume (Fig. 2a). Net $\mathrm{O}_{2}$ consumption by the benthic community was apparent from a decrease in the $\mathrm{O}_{2}$ concentration, while net production was seen as an increase in $\mathrm{O}_{2}$ concentration. Oxygen microprofiles were measured in the same set-up after removal of the transparent lid and ensuring $100 \%$ air saturation of the overlying water phase (Fig. 2b).

Each core was incubated in darkness and at $140 \mu \mathrm{mol}$ photons $\mathrm{m}^{-2} \mathrm{~s}^{-1}$ at each temperature. After changing the irradiance, cores were pre-incubated for $45 \mathrm{~min}$ prior to any measurements to ensure quasi steady state (this was confirmed by repeated microsensor measurements). To study impacts of temperatures, the ambient temperature was increased stepwise by $3^{\circ} \mathrm{C}$. All cores were initially incubated at the lowest temperature. After a temperature change, the cores were preincubated for $60 \mathrm{~min}$ to obtain quasi steady state. At each temperature level, the measuring period lasted for approximately $3 \mathrm{~h}$. Consequently, all cores experienced the same 'temperature history'.

The time required to ensure quasi steady state was determined by repeated microprofiling (every 5 to 10 min). Further, preliminary investigations confirmed that the order of temperature change had no effect on the community response in the interval from -1 to $18^{\circ} \mathrm{C}$. However, after exposure to temperatures $>18^{\circ} \mathrm{C}$, the community rates were not always re-established when temperatures were subsequently lowered (data not shown).

Diffusive oxygen exchange (DOE) measurements. DOE rate was estimated from the diffusive flux of $\mathrm{O}_{2}$ between the sediment and the water $\left(J_{\text {up }}\right)$ as calculated from steady-state $\mathrm{O}_{2}$ concentration profiles (Figs. $2 b$ \& 3). $J_{\text {up }}$ was determined from the linear concentration gradient within the DBL, using Fick's first law of diffusion (Eq. 1 in Fig. 3a) (Jørgensen \& Revsbech 1985, Crank 1989). Symbols and abbreviations used throughout the paper are listed in Table 2.

Oxygen profiles across the benthic interface were obtained with a vertical resolution of 50 to $100 \mu \mathrm{m}$. The thickness of the oxic zone $\left(\mathrm{O}_{2}\right.$-pd) was directly deter- 
mined from the measured profiles accounting for the observed thickness of DBL. The sediment dark respiration $\left(R_{\text {dark }}\right)$ was estimated as the flux of $\mathrm{O}_{2}$ into the sediment $\left(-J_{\text {up }}\right)$ from the overlying water (Eq. 1 in Fig. 3a). The average specific sediment respiration $\left(R_{\text {dark,vol }}\right)$, defined as the integrated average volumetric respiration of the oxic zone, was calculated by dividing $R_{\mathrm{dark}}$ with $\mathrm{O}_{2}$-pd (Eq. 2 in Fig. 3a).

Net photosynthesis $\left(P_{\mathrm{n}}\right)$ in light equalled the flux of $\mathrm{O}_{2}$ out of the sediment $\left(J_{\text {up }}\right)$ towards the overlying water (Eq. 6 in Fig. 3b). The specific net photosynthesis of the production zone $\left(P_{\mathrm{n}, \mathrm{vol}}\right)$ was calculated as the total flux of $\mathrm{O}_{2}$ out of the production zone, i.e. the sum of the flux to the overlying water $\left(J_{\text {up }}\right)$ and the downward flux to the non-production zone $\left(J_{\text {down }}\right)$ (Eq. 7 in Fig. 3b) divided by the thickness of the production zone (Eq. 8 in Fig. 3b) (Glud et al. 1992, Kühl et al. 1996). $J_{\text {down }}$ was determined from the turning tangent to the $\mathrm{O}_{2}$ profile at the boundary between the production and the non-production zones. The production zone was defined as the upper oxic zone delimited downward by the horizon of the compensation point, i.e. where the gross $\mathrm{O}_{2}$ production equalled the $\mathrm{O}_{2}$ consumption at incident surface irradiance of $140 \mu \mathrm{mol}$ photons $\mathrm{m}^{-2} \mathrm{~s}^{-1}$ (Fig. 3b). The production zone is not identical to the photic sediment zone; however, in the present study the actual production zone is in focus. The light attenuation within the investigated sediments was not determined but supposed similar to the light attenuation measured by Kühl \& Jørgensen (1994) in similar coastal sandy sediments. The non-production zone was defined as the oxic zone beneath the production zone.

In addition to $R_{\mathrm{dark}}$ and $R_{\mathrm{dark}, \mathrm{vol},}$ the specific respiration of the separated production and non-production zones was calculated. The specific dark respiration rate of the production zone ( $\left.R_{\mathrm{dark}, \text { vol,prod }}\right)$ was calculated as the $\mathrm{O}_{2}$ flux into the production zone $\left(-J_{\text {up }}\right)$ minus the $\mathrm{O}_{2}$ flux down to the nonproduction zone $\left(J_{\text {down }}\right)$, accounting for the thickness of the production zone (Eq. 4 in Fig. 3a). Consequently, the dark respiration rate of the non-production zone $\left(R_{\text {dark,vol,nprod }}\right)$ was calculated as the downward flux to the non-production zone $\left(J_{\text {down }}\right)$ accounting for the thickness of the oxic nonproduction zone (Eq. 5 in Fig. 3a). The oxygen profiles were measured at spots with high microphytic biomass in order to study the temperature response of respiration and photosynthesis. For this reason, the measured DOE rates were not always representative for the entire core area.

For $\mathrm{O}_{2}$ flux calculation in the sediment, the effective diffusion coefficient of $\mathrm{O}_{2}\left(D_{\mathrm{s}}\right)$ was derived from the molecular diffusion coefficient of $\mathrm{O}_{2}\left(D_{\mathrm{o}}\right)$ and the sediment porosity $(\phi)$, according to Ullmann \& Aller (1982) (Eq. 9). The $D_{\mathrm{o}}$ was from Broecker \& Peng (1974) and corrected for temperature and salinity as described by Li \& Gregory (1974).

$$
D_{\mathrm{s}}=\phi \cdot D_{\mathrm{o}}
$$

Table 2. Definition of abbreviations

\begin{tabular}{|c|c|}
\hline Abbreviation & Definition \\
\hline DBL & Diffusive boundary layer \\
\hline TOE & $\begin{array}{l}\text { Total oxygen exchange } \\
\text { (whole core consumption/production rates) }\end{array}$ \\
\hline DOE & $\begin{array}{l}\text { Diffusive oxygen exchange } \\
\text { (diffusive consumption/production rates) }\end{array}$ \\
\hline$C(z)$ & Oxygen concentration at depth $z\left(\mathrm{nmol} \mathrm{cm}^{-3}\right)$ \\
\hline$D_{\mathrm{o}}$ & Molecular diffusion coefficient of oxygen in water $\left(\mathrm{cm}^{2} \mathrm{~s}^{-1}\right)$ \\
\hline$D_{\mathrm{s}}$ & $\begin{array}{l}\text { Effective diffusion coefficient of oxygen in sediment } \\
\left(\mathrm{cm}^{2} \mathrm{~s}^{-1}\right)\end{array}$ \\
\hline depth $_{\text {prod }}$ & Thickness of production zone \\
\hline depth $_{\text {nprod }}$ & Thickness of non-production zone \\
\hline$E_{\mathrm{a}}$ & Apparent activation energy $\left(\mathrm{kJ} \mathrm{mol}^{-1}\right)$ \\
\hline$J_{\text {down }}$ & $\begin{array}{l}\text { Flux of } \mathrm{O}_{2} \text { from the production zone to the non-production } \\
\text { zone }\left(\mathrm{nmol} \mathrm{O} \mathrm{Cm}_{2}^{-2} \mathrm{~s}^{-1}\right)\end{array}$ \\
\hline$J_{\text {up }},-J_{\text {up }}$ & Flux of $\mathrm{O}_{2}$ across the DBL $\left(\mathrm{nmol} \mathrm{O}_{2} \mathrm{~cm}^{-2} \mathrm{~s}^{-1}\right)$ \\
\hline$R_{\text {dark }}(\mathrm{DOE})$ & Areal sediment respiration in darkness $\left(\mathrm{nmol} \mathrm{O} \mathrm{cm}^{-2} \mathrm{~s}^{-1}\right)$ \\
\hline$R_{\mathrm{dark}, \mathrm{vol}}$ & Specific sediment respiration in darkness $\left(\mathrm{nmol} \mathrm{O}_{2} \mathrm{~cm}^{-3} \mathrm{~s}^{-1}\right)$ \\
\hline$R_{\text {dark,vol,prod }}$ & $\begin{array}{l}\text { Specific respiration of the production zone }{ }^{\mathrm{a}} \text { in darkness } \\
\left(\mathrm{nmol} \mathrm{O} \mathrm{Cm}^{-3} \mathrm{~s}^{-1}\right)\end{array}$ \\
\hline$R_{\text {dark,vol,nprod }}$ & $\begin{array}{l}\text { Specific respiration of the non-production zone }{ }^{\mathrm{b}} \text { in darkness } \\
\left(\mathrm{nmol} \mathrm{O}_{2} \mathrm{~cm}^{-3} \mathrm{~s}^{-1}\right)\end{array}$ \\
\hline$P_{\mathrm{n}}(\mathrm{DOE})$ & $\begin{array}{l}\text { Areal net photosynthesis of the sediment in light } \\
\left(\mathrm{nmol} \mathrm{O} \mathrm{Cm}^{-2} \mathrm{~s}^{-1}\right)\end{array}$ \\
\hline$P_{\mathrm{n}, \mathrm{vol}}$ & $\begin{array}{l}\text { Specific net photosynthesis of the production zone } \\
\left(\mathrm{nmol} \mathrm{O} \mathrm{Cm}^{-3} \mathrm{~s}^{-1}\right)\end{array}$ \\
\hline$P_{\text {gross }}$ & $\begin{array}{l}\text { Areal gross photosynthesis of the production zone } \\
\left(\mathrm{nmol} \mathrm{O} \mathrm{Cm}^{-2} \mathrm{~s}^{-1}\right)\end{array}$ \\
\hline$P_{\text {gross, vol }}$ & Volumetric gross photosynthesis $\left(\mathrm{nmol} \mathrm{O}_{2} \mathrm{~cm}^{-3} \mathrm{~s}^{-1}\right.$ ) \\
\hline$P_{(z)}$ & $\begin{array}{l}\text { Volumetric gross photosynthesis at depth } z \\
\left(\mathrm{nmol} \mathrm{O}_{2} \mathrm{~cm}^{-3} \mathrm{~s}^{-1}\right)\end{array}$ \\
\hline $\mathrm{O}_{2}-\mathrm{pd}$ & Oxygen penetration depth in the sediment \\
\hline \multicolumn{2}{|c|}{$\begin{array}{l}\text { The production zone was defined as the upper } 1.0 \text { to } 1.2 \mathrm{~mm} \text { of the sediment } \\
\text { having a net } \mathrm{O}_{2} \text { production in light } \\
\text { b The non-production zone was defined as the oxic zone immediately } \\
\text { beneath the production zone. The oxic zone was defined as the upper sedi- } \\
\text { ment zone with a }\left[\mathrm{O}_{2}\right]>1 \mathrm{nmol} \mathrm{O}_{2} \mathrm{~cm}^{-3}\end{array}$} \\
\hline
\end{tabular}


Fig. 3. Eqs. (1) to (8) for calculating diffusive $\mathrm{O}_{2}$ consumption and production rates from steady-state $\mathrm{O}_{2}$ concentration profiles in (a) darkness and (b) light, respectively. See Table 2 for definition of abbreviations. For calculations performed in the DBL, $D_{\mathrm{o}}$ was applied, but for calculations in the sediment, $D_{0}$ was replaced by $D_{\mathrm{s}}$ (see text). The DBL and the production and the non-production zones of the sediment are shown in each panel. All flux measurements were performed under steady-state conditions and calculations were based on Fick's 1st law of diffusion. Inspired by Kühl et al. (1996)
Diffusive $\mathrm{O}_{2}$ exchange calculations

$$
\begin{aligned}
& \text { Dark: } \\
& R_{\text {dark }}=-J_{\text {up }}=-D_{\mathrm{o}} \frac{\mathrm{d} C(\mathrm{z})}{\mathrm{d} z} \\
& R_{\text {dark,vol }}=\frac{-J_{\text {up }}}{O_{2}-\mathrm{pd}} \\
& J_{\text {down }}=D_{\mathrm{s}} \frac{\mathrm{d} C(\mathrm{z})}{\mathrm{d} z} \\
& R_{\text {dark,vol,prod }}=\frac{\left(-J_{\text {up }}\right)+J_{\text {down }}}{\text { depth }_{\text {prod }}} \\
& R_{\text {dark,vol,nprod }}=\frac{J_{\text {down }}}{\text { depth }_{\text {nprod }}}
\end{aligned}
$$

(5)

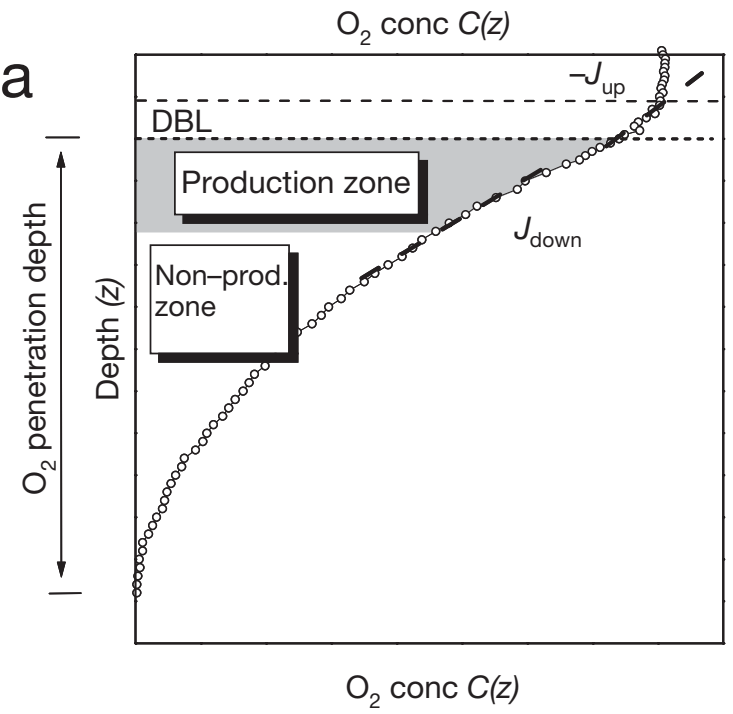

Light:

$$
\begin{aligned}
& P_{\mathrm{n}}=J_{\text {up }}=D_{\mathrm{s}} \frac{\mathrm{d} C(\mathrm{z})}{\mathrm{d} z} \\
& J_{\text {down }}=D_{\mathrm{s}} \frac{\mathrm{d} C(\mathrm{z})}{\mathrm{d} z} \\
& P_{\mathrm{n}, \mathrm{vol}}=\frac{J_{\text {up }}+J_{\text {down }}}{\text { depth }_{\text {prod }}}
\end{aligned}
$$

(6)

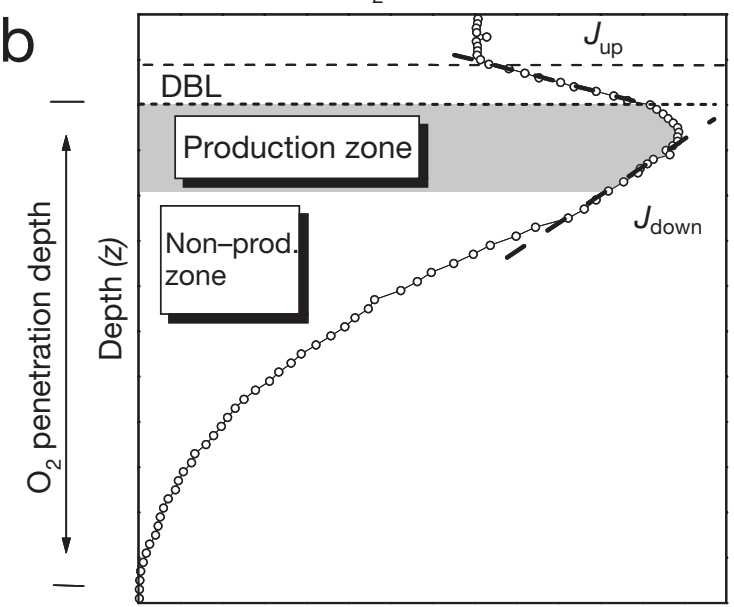

Steady-state oxygen profiles were confirmed in each experiment by comparing 2 or more profiles measured within a time interval of 5 to $20 \mathrm{~min}$.

Gross photosynthesis. Gross photosynthesis at depth $z_{1} P(z)$, was measured by the light-dark shift method. This approach estimates the gross $\mathrm{O}_{2}$ production from the initial decrease of $\mathrm{O}_{2}$ after a sudden eclipse of light (Revsbech \& Jørgensen 1983, Glud et al. 1992). The $\mathrm{O}_{2}$ concentration was recorded continuously for 4 s during a light-dark shift. Repetitive measurements at 5 min intervals were performed at the same position. A photoelectrical cell connected to the flatbed recorder was used to obtain the exact timing for the onset of darkness.

Two practical approaches were applied to obtain the gross photosynthetic rate as a function of temperature. In Approach 1, we depth-integrated the gross photosynthesis of the entire production zone $\left(P_{\text {gross }}\right)$. In this approach, an electrode sensor tip was placed at the very surface of the sediment and then moved down- ward in steps of $100 \mu \mathrm{m} . P(z)$ was measured at each depth, using the light-dark shift method, until the measured rates approached zero at the bottom of the production zone. Temperature was kept constant until a complete vertical gross photosynthesis profile was obtained (Glud et al. 1992, Kühl et al. 1996).

Approach 2 did not include profiling, and gross photosynthesis was solely obtained at the depth of the maximum activity within the production zone $\left(P_{\text {gross, vol }}\right)$. In this approach, the microsensor tip was carefully placed at the given position, and subsequently temperature was changed $<6^{\circ} \mathrm{C} \mathrm{h}^{-1}$ while performing light-dark shifts every 10 to $20 \mathrm{~min}$. $P_{\text {gross }}$ rates were calculated using Fick's second law of diffusion simplified according to Revsbech et al. (1986):

$$
P(z)=-\frac{\mathrm{d} C(z, t)}{\mathrm{d} t}
$$

The gross $\mathrm{O}_{2}$ production $P(z)$ equals the initial linear decrease of the $\mathrm{O}_{2}$ concentration $C(z, t)$ at a specific 
depth $(z)$ over time $(t)$. For a more detailed discussion of the technique and the required assumptions, see Glud et al. (1992).

Slurry experiments. Apart from the measurements in intact benthic communities, slurry experiments on re-suspended samples from the Trondheimsfjord were performed in darkness. The oxic, production and nonproduction zones of the sediment were incubated in parallel by resuspending sediment samples (equivalent to $\sim 100 \mathrm{~g}_{\text {dry matter }} \mathrm{l}^{-1}$ ) in seawater from the sampling site. The boundaries of the production and the oxic zones were determined from $\mathrm{O}_{2}$ microprofiles measured prior to core slicing. Before suspension of the sediments, fauna visual to the naked eye was carefully removed from the slurries. The sediment slurries were placed in the thermo-regulated water bath (Fig. 2) and air-flushed for $30 \mathrm{~min}$ prior to the experiment to ensure air-saturation and oxidation of reduced inorganic substances. All slurries were stirred with a magnetic stirrer in the time period prior to and during the measurements. Any potential $\mathrm{O}_{2}$ consumption by bacteria in the added seawater was assumed minor and ignored (Thamdrup et al. 1998). Oxygen consumption was measured after closing the samples, avoiding bubbles and placing a microelectrode in the chamber lid. The $\mathrm{O}_{2}$ consumption was measured continuously for each incubation and was in all cases linear. The temperature was kept constant during each incubation, and the incubations were performed at temperature steps between 0 and $48^{\circ} \mathrm{C}$. Each incubation period was adjusted to ensure a total $\mathrm{O}_{2}$ concentration change of 10 to $30 \%$.

Arrhenius plot and $\boldsymbol{Q}_{10}$ calculations. The effect of temperature on respiration rates, net photosynthetic and gross photosynthetic rates was quantified by calculating the apparent activation energy $\left(E_{\mathrm{a}}\right.$ in $\left.\mathrm{kJ} \mathrm{mol}^{-1}\right)$ and the corresponding $Q_{10}$ value for each type of data set. $E_{\mathrm{a}}$ was calculated as the slope of the available data point from the initial linear part of an Arrhenius plot (temperature < optimum), where $\ln (k)$ was plotted as a function of temperature $(R T)^{-1}$, according to Raven \& Geider (1988) and Isaksen \& Jørgensen (1996) as:

$$
\ln (k)=\ln (A)+\left[-E_{\mathrm{a}}(R T)^{-1}\right]
$$

where $k$ is the rate of the reaction, $A$ is the Arrhenius constant, $R$ is the gas constant $\left(8.3144 \mathrm{~J} \mathrm{~K}^{-1} \mathrm{~mol}^{-1}\right)$ and $T$ is the absolute temperature $(\mathrm{K}) . E_{\mathrm{a}}$ is not the chemical activation energy but the overall temperature response of respiration or photosynthesis within the entire sediment community. The $Q_{10}$ value was calculated from Eq. (12), where $E_{\mathrm{a}}$ quantifies the increase of the reaction rate. In all cases, a temperature interval from 0 to $10^{\circ} \mathrm{C}$ was used in the calculation of $Q_{10}$. Standard errors (SE) were obtained for $E_{\mathrm{a}}$ based on the linear regressions $(p=0.05)$.

$$
Q_{10}=\exp \left\{E_{\mathrm{a}} \cdot 10[R T(T+10)]^{-1}\right\}
$$

Measured rates of respiration, as well as gross and net photosynthesis, were compared between sites. A statistical analysis of covariance (ANCOVA) was performed to test for insignificance of the $Q_{10}$ values between sites, as the rate $\times$ site interaction computed by S-PLUS 6.2. ANCOVA assumes statistically independent values. The experimental design of the present study, however, does not offer completely independent data due to the repeated measurements on the incubated cores. We, however, judged that this had little effect on the obtained statistical results and we found no superior statistical model to fit the present study.

\section{RESULTS}

\section{Total $\mathrm{O}_{2}$ exchange rates}

TOE rates were measured in darkness and at $140 \mu \mathrm{mol}$ photons $\mathrm{m}^{-2} \mathrm{~s}^{-1}$ as a function of temperature (Fig. 4). The negative TOE rates in darkness reflect sediment $\mathrm{O}_{2}$ consumption (influx of $\mathrm{O}_{2}$ ), whereas the positive TOE rates in light reflect net $\mathrm{O}_{2}$ production (efflux of $\mathrm{O}_{2}$ ). In darkness, the $\mathrm{O}_{2}$ consumption increased exponentially with increasing temperature at all the investigated sites. No optimum temperature was observed between -1 and $21^{\circ} \mathrm{C}$. To compare the temperature response between sites, $Q_{10\left(0-10^{\circ} \mathrm{C}\right)}$ values were calculated from the apparent $E_{\mathrm{a}}$ based on the linear slope of the Arrhenius plots (Fig. 4d). The calculated $Q_{10}$ values for the dark-incubated cores were 3.3, 2.4 and 2.4 for Nivå Bay, the Trondheimsfjord, and the Adventfjord, respectively. $E_{\mathrm{a}} \pm \mathrm{SE}$ and $Q_{10}$ values are presented in Table 3.

In light, the TOE rates increased gradually with increasing temperature to a maximum at temperatures between 6 and $12^{\circ} \mathrm{C}$, followed by a decrease (Fig. 4). The $Q_{10}$ values for TOE in light were 1.7, 2.4 and 1.5 for Nivå Bay, the Trondheimsfjord, and the Adventfjord, respectively (Fig. 4e, Table 3 ).

For TOE in the dark, no significant difference of the $Q_{10}$ was observed between the Trondheimsfjord and the Adventfjord ( $\mathrm{p}>0.05)$; however, a significant difference ( $p=0.01)$ between the 3 sites was observed, as $E_{\mathrm{a}}$ for Nivå Bay was higher than for the 2 other sites. For TOE in light, there was no significant difference of the $Q_{10}$ between the 3 sites $(\mathrm{p}=0.59)$. In all cases, increasing temperature stimulated heterotrophic activity more than photosynthesis, gradually shifting the otherwise net autotrophic sediment community towards a greater predominance of heterotrophic activity. Temperature effects on total oxygen exchange rates, however, essentially represent a 'black box' 

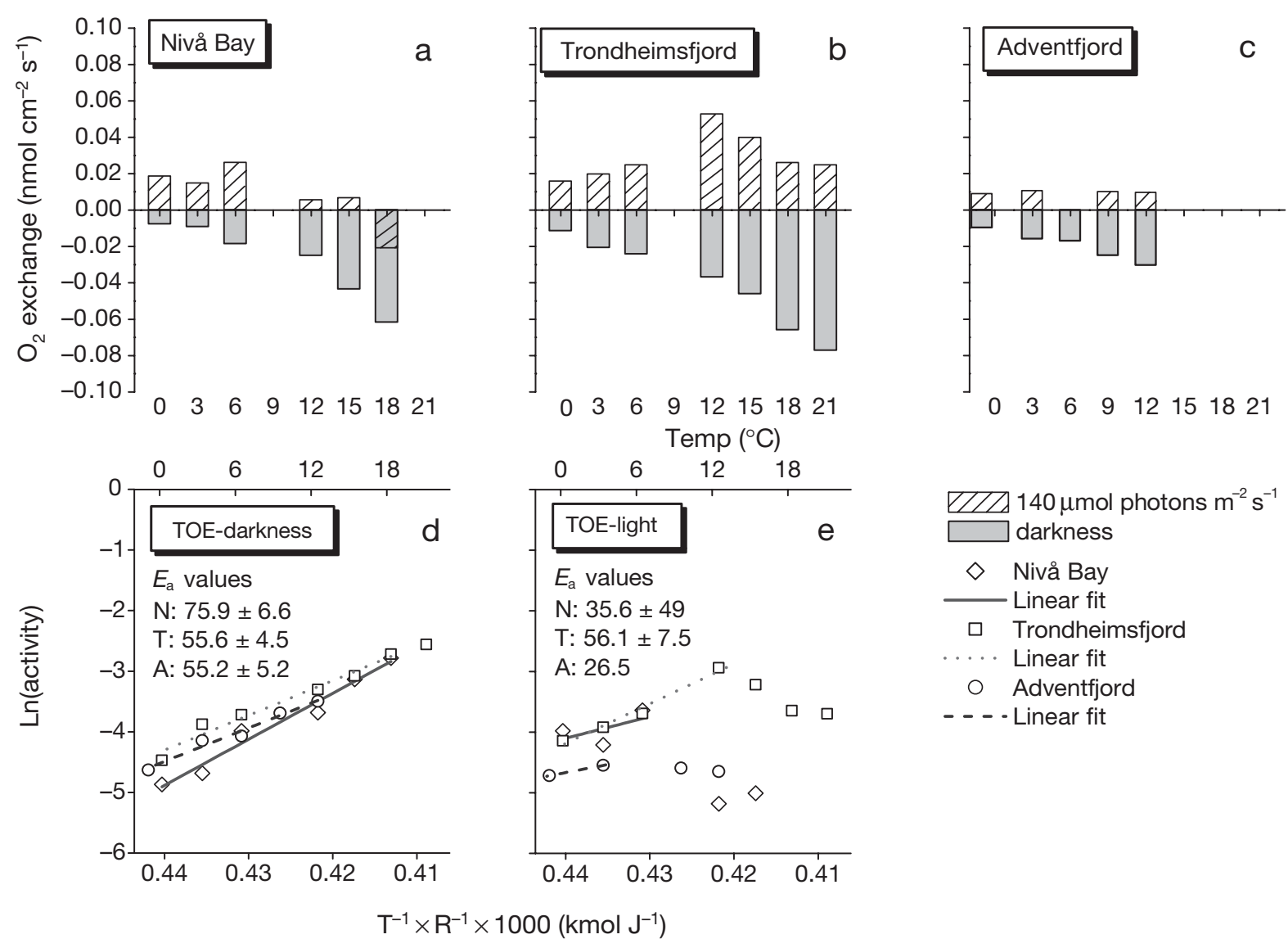

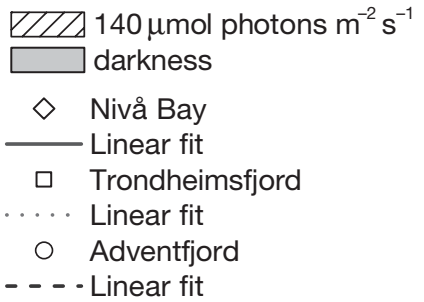

Fig. 4. Areal rates of total oxygen exchange (TOE) as a function of temperature, measured from whole core incubations in darkness and at $140 \mu \mathrm{mol}$ photons $\mathrm{m}^{-2} \mathrm{~s}^{-1}$ in (a) Nivå Bay, (b) the Trondheimsfjord and (c) the Adventfjord. Negative values indicate net $\mathrm{O}_{2}$ consumption and positive values net $\mathrm{O}_{2}$ production. Rates from each site were plotted in Arrhenius plots in (d) darkness and (e) light. The activation energy $\left(E_{\mathrm{a}} \pm \mathrm{SE}_{;} \mathrm{kJ} \mathrm{mol}^{-1}\right)$ was calculated from the initial linear fit (d, e), labelled N (Nivå Bay), $\mathrm{T}$ (Trondheimsfjord) and A (Adventfjord). Corresponding $Q_{10}$ values are shown in Table 3

approach confounded by changes in the $\mathrm{O}_{2}$ penetration depth, DBL thickness, diffusion coefficients, etc., and yields limited information on the actual microbial temperature response. This, however, can be derived from micro-profile measurements.

\section{Diffusive $\mathrm{O}_{2}$ exchange rates in darkness}

With increasing temperature, the $\mathrm{O}_{2}$ solubility decreases while the molecular diffusion coefficient increases. In order to extract the biological response of the intact community, detailed microsensor measurements at the different experimental settings are required. Steady-state $\mathrm{O}_{2}$ microprofiles were measured at temperatures from -1 to $21^{\circ} \mathrm{C}$, and the corresponding DOE rates were calculated. In darkness, DOE rates increased exponentially with increasing temperature while the $\mathrm{O}_{2}$-pd decreased (Fig. 5). The $Q_{10\left(0-10^{\circ} \mathrm{C}\right)}$ values for DOE in darkness were 2.2, 1.7 and 2.4 for Nivå Bay, Trondheimsfjord and Adventfjord, respectively $\left(E_{\mathrm{a}} \pm \mathrm{SE}\right.$ and $Q_{10}$ are presented in Fig. 5d \& Table 3), and were not significantly different between the 3 sites $(p=0.19)$. The $Q_{10}$ values in darkness, at the selected spots that were dominated by phototrophs, tended to be lower than for the TOE, which integrates the response of the entire sediment area. This supports the observation of lower $Q_{10}$ values for the autotrophic activity compared to the heterotrophic activity. $Q_{10}$ for $\mathrm{O}_{2}$-pd were $0.42,0.64$ and 0.73 for Nivå Bay, the Trondheimsfjord and the Adventfjord, respectively (Fig. 5e, Table 3). The decrease in $\mathrm{O}_{2}$-pd with decreasing temperature led to a lower volume of oxic sediment. The specific respiration rates $\left(R_{\text {dark, vol }}\right)$ (for method see Fig. 3) were thereby strongly stimulated by increasing temperature, with $Q_{10}$ values of 5.2, 2.6 and 3.2 for Nivå Bay, the Trondheimsfjord and the Adventfjord, respectively $\left(E_{\mathrm{a}} \pm\right.$ SE and $Q_{10}$ are presented in Fig. 5f \& Table 3). However, the $Q_{10}$ for Nivå Bay was slightly higher than for the 2 other sites; the difference was not significant $(p=0.06)$. The biological temperature response for the community 
was, hence, significantly stronger than was obtained from simple flux measurements.

\section{Production and non-production zone respiration}

The oxic zone of the sediment was divided into an upper production zone and a lower non-production zone, to some extent reflecting the natural zonation of microbes (Fig. 3) (e.g. MacIntyre \& Cullen 1995, Epping \& Jørgensen 1996). Based on measured $\mathrm{O}_{2}$ profiles in darkness, specific consumption rates were calculated for each zone, as $R_{\mathrm{dark}, \text { vol, prod }}$ and $R_{\mathrm{dark}, \text { vol,nprod, }}$ respectively. The $\mathrm{O}_{2}$ consumption rates were overall higher ( 1 to 6 times) for the production zone than for the non-production zone (Fig. 6). However, the $Q_{10}$ values tended to be higher for the non-production than for the production zone, the exception being the Adventfjord, which exhibited very low microphytic biomass (Table 4). The higher $Q_{10}$ response in Nivå Bay and the Trondheimsfjord for non-production zone respiration supports the previous observation of heterotrophs being more sensitive to temperature changes compared to the autotroph organisms.

\section{Gross photosynthesis}

Due to the relatively low biomass of microphytes at the Adventfjord (Table 1), it was not possible to make robust gross photosynthetic measurements at that location. Depth-integrated rates of gross photosynthesis $\left(P_{\text {gross }}\right)$ (Approach 1, see 'Materials and methods') were determined as a function of temperature only for the Trondheimsfjord, whereas point measurements $\left(P_{\text {gross, vol }}\right)$ (Approach 2) were carried out in both Nivå Bay and the Trondheimsfjord.

$P_{\text {gross }}$ rates were obtained from integrating vertical profiles of gross photosynthesis across the production zone, for each temperature (Fig. 7). The shape of the profiles was similar during changing temperature, demonstrating a constant activity distribution with depth and, hence, no vertical shift in the photosynthetic activity was observed. The $P_{\text {gross }}$ rate showed a linear response with increasing temperature from $0^{\circ} \mathrm{C}$ to the optimum temperature $\left(T_{\text {opt }}\right)$ at $12^{\circ} \mathrm{C}$, with a $Q_{10}$ value of 3.1 (Fig. 8d, Table 3). The $P_{\text {gross,vol }}$ rate, based on point measurements, showed a response similar to $P_{\text {gross }}$ obtained both in the Trondheimsfjord and in Nivå Bay. For the Trondheimsfjord, $T_{\text {opt }}$ was $12^{\circ} \mathrm{C}$ and $Q_{10}$ for $P_{\text {gross, vol }}$ was 2.6 (Fig. $8 \mathrm{~b}, \mathrm{~d}, Q_{10}$ and $E_{\mathrm{a}}$ in Table 3). For Nivå Bay, $T_{\mathrm{opt}}$ was $15^{\circ} \mathrm{C}$ and $Q_{10} 2.2$ (Fig. 8a,c, $Q_{10}$ and $E_{\mathrm{a}}$ in Table 3 ). Conclusively, the point measurements confirmed the same trend as the depth-integrated approach.
Table 3. $Q_{10}$ values (upper values) of respiration, net production and gross photosynthesis, calculated from the activation energies $\left(E_{\mathrm{a}}\right)$ (lower values) from Figs. 4, 5, $8 \&$ 9. $E_{\mathrm{a}} \pm \mathrm{SE}\left(\mathrm{kJ} \mathrm{mol}^{-1}\right)$ is given below the $Q_{10}, \mathrm{n}$ is number of regression points

\begin{tabular}{|c|c|c|c|}
\hline & Nivå Bay & Trondheimsfjord & Adventfjord \\
\hline \multicolumn{4}{|l|}{ Darkness } \\
\hline TOE & $\begin{array}{l}3.3(\mathrm{n}=6) \\
75.9 \pm 6.6\end{array}$ & $\begin{array}{c}2.4(\mathrm{n}=15) \\
55.6 \pm 4.5\end{array}$ & $\begin{array}{l}2.4(\mathrm{n}=5) \\
55.2 \pm 5.2\end{array}$ \\
\hline $\mathrm{DOE}\left(R_{\mathrm{dark}}\right)$ & $\begin{array}{c}2.2(\mathrm{n}=6) \\
50.0 \pm 10\end{array}$ & $\begin{array}{c}1.7(\mathrm{n}=12) \\
33.5 \pm 6.2\end{array}$ & $\begin{array}{c}2.4(\mathrm{n}=5) \\
56.0 \pm 12\end{array}$ \\
\hline $\mathrm{O}_{2}$-pd & $\begin{array}{l}0.42(\mathrm{n}=6) \\
-55.9 \pm 3.4\end{array}$ & $\begin{array}{c}0.64(\mathrm{n}=12) \\
-27.1 \pm 4.9\end{array}$ & $\begin{array}{l}0.73(\mathrm{n}=5) \\
-20.0 \pm 7.3\end{array}$ \\
\hline$R_{\text {dark, vol }}$ & $\begin{array}{c}5.2(\mathrm{n}=6) \\
105 \pm 13\end{array}$ & $\begin{array}{c}2.6(n=12) \\
61.8 \pm 10\end{array}$ & $\begin{array}{l}3.2(\mathrm{n}=5) \\
75.0 \pm 17\end{array}$ \\
\hline $\begin{array}{l}\text { Slurry } \\
\text { respiration }\end{array}$ & - & $\begin{array}{l}1.7(\mathrm{n}=7) \\
35.7 \pm 9.3\end{array}$ & - \\
\hline \multicolumn{4}{|l|}{ Light } \\
\hline TOE & $\begin{array}{l}1.7(\mathrm{n}=3) \\
35.6 \pm 49\end{array}$ & $\begin{array}{l}2.4(\mathrm{n}=7) \\
56.1 \pm 7.5\end{array}$ & $\begin{array}{c}1.5(\mathrm{n}=2) \\
26.5\end{array}$ \\
\hline $\operatorname{DOE}\left(P_{\mathrm{n}}\right)$ & $\begin{array}{l}1.4(\mathrm{n}=3) \\
23.5 \pm 7.3\end{array}$ & $\begin{array}{c}2.2(\mathrm{n}=4) \\
50.2 \pm 11\end{array}$ & $\begin{array}{c}1.6(n=5) \\
31.1 \pm 13\end{array}$ \\
\hline $\mathrm{O}_{2}$-pd & $\begin{array}{l}0.78(\mathrm{n}=4) \\
-16.0 \pm 12\end{array}$ & $\begin{array}{l}0.82(\mathrm{n}=4) \\
-12.4 \pm 3.3\end{array}$ & $\begin{array}{l}0.78(n=5) \\
-15.7 \pm 6.4\end{array}$ \\
\hline$P_{\mathrm{n}, \mathrm{vol}}$ & $\begin{array}{l}1.5(\mathrm{n}=3) \\
24.6 \pm 2.2\end{array}$ & $\begin{array}{c}2.1(\mathrm{n}=4) \\
46.3 \pm 11\end{array}$ & $\begin{array}{l}1.6(\mathrm{n}=5) \\
30.4 \pm 6.8\end{array}$ \\
\hline$P_{\text {gross }}$ & - & $\begin{array}{c}3.1(\mathrm{n}=4) \\
73.6 \pm 11\end{array}$ & - \\
\hline$P_{\text {gross,vol }}$ & $\begin{array}{c}2.2(\mathrm{n}=10) \\
50.9 \pm 7.0\end{array}$ & $\begin{array}{c}2.6(\mathrm{n}=13) \\
62.5 \pm 11\end{array}$ & - \\
\hline
\end{tabular}

\section{Diffusive $\mathrm{O}_{2}$ exchange rates in light}

The net photosynthetic rate integrates the gross $\mathrm{O}_{2}$ production (production zone) and the $\mathrm{O}_{2}$ consumption (in light) of the entire oxic zone. Net photosynthetic rates $\left(P_{\mathrm{n}}\right)$ were calculated from $\mathrm{O}_{2}$ microprofiles in light $\left(140 \mu \mathrm{mol} \mathrm{m} \mathrm{m}^{-2} \mathrm{~s}^{-1}\right)$ (Fig. 9a-c). The light-induced response was highest in Nivå Bay and lowest in the Adventfjord, reflecting the microphytic biomass at the respective sites. Generally, the $\mathrm{O}_{2}$ concentration and the $\mathrm{O}_{2}$-pd of the benthic community decreased with increasing temperature. Calculated rates of $P_{\mathrm{n}}$ increased continuously with temperature from $0^{\circ} \mathrm{C}$ to $T_{\text {opt, }}$ at all sites (Fig. 9d). Rates for Nivå Bay and the Trondheimsfjord showed a subsequent decrease above $T_{\text {opt }}$ which was $12^{\circ} \mathrm{C}$ for the Trondheimsfjord and the Adventfjord and $15^{\circ} \mathrm{C}$ for Nivå Bay. Calculated $Q_{10}$ values for $P_{\mathrm{n}}$, derived from the Arrhenius plot, were 1.4, 2.2 and 1.6 for Nivå Bay, the Trondheimsfjord and the Adventfjord, respectively ( $E_{\mathrm{a}}$ in Fig. 9 d, including $Q_{10}$ in Table 3), and were not significantly different ( $\mathrm{p}=$ 0.47). The Adventfjord showed lower absolute rates than for the 2 other sites. No rates were obtained for the Adventfjord at temperatures $>12^{\circ} \mathrm{C}$. 

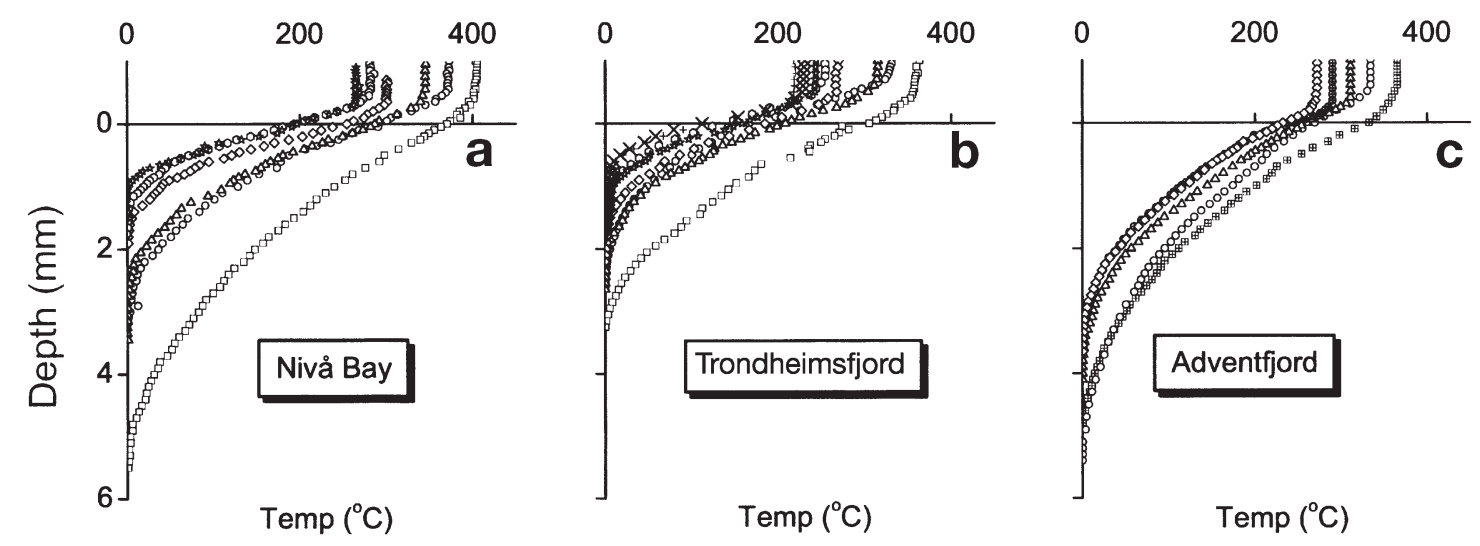

$\begin{array}{lr}\rightarrow & -1^{\circ} \mathrm{C} \\ \square & 0^{\circ} \mathrm{C} \\ \circ & 3^{\circ} \mathrm{C} \\ \triangle & 6^{\circ} \mathrm{C} \\ \oplus & 9^{\circ} \mathrm{C} \\ \diamond & 12^{\circ} \mathrm{C} \\ 0 & 15^{\circ} \mathrm{C} \\ \text { \& } & 18^{\circ} \mathrm{C} \\ \times & 21^{\circ} \mathrm{C} \\ + & 24^{\circ} \mathrm{C}\end{array}$
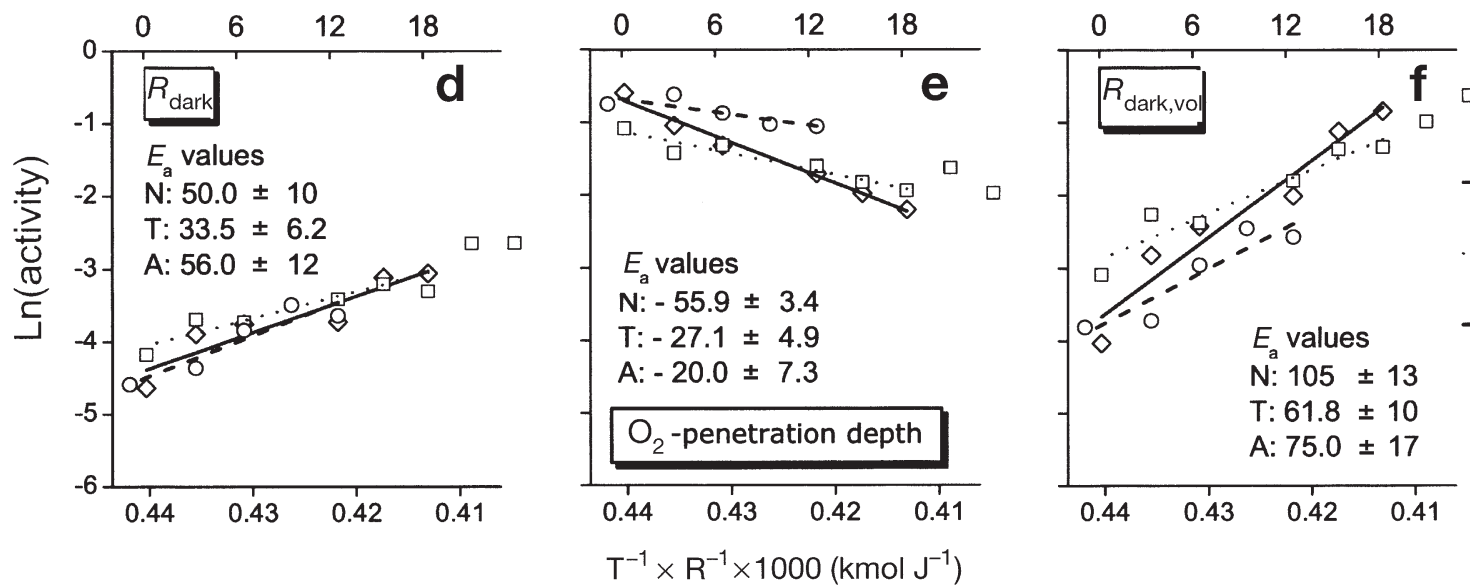

$\diamond \quad$ Nivå Bay

$\square$ Trondheimsfjord

.... Linear fit

- Adventfjord

- - - - Linear fit

$\mathrm{T}:-27.1 \pm 4.9$

A: $-20.0 \pm 7.3$

$\times R^{-1} \times 1000(\mathrm{kmol} \mathrm{J-1})$

Fig. 5. Steady-state $\mathrm{O}_{2}$ microprofiles in intact sediment cores in darkness at various temperatures $\left(-1\right.$ to $\left.24^{\circ} \mathrm{C}\right)$ from (a) Nivå Bay, (b) the Trondheimsfjord and (c) the Adventfjord. Arrhenius plots of (d) diffusive $\mathrm{O}_{2}$ consumption $\left(R_{\text {dark }}\right)$ calculated from the slope of the profile in DBL, (e) the oxygen penetration depth and (f) the specific respiration as a function of temperature are shown. Activation energies $\left(E_{\mathrm{a}} \pm \mathrm{SE} ; \mathrm{kJ} \mathrm{mol}^{-1}\right)$ are included $(\mathrm{d}-\mathrm{f})$, labelled $\mathrm{N}$ (Nivå Bay), T (Trondheimsfjord) and $\mathrm{A}$ (Adventfjord). Corresponding $Q_{10}$ values are shown in Table 3

Table 4. $Q_{10}$ values (upper values) of the production and nonproduction zone-specific respiration based on the activation energies $\left(E_{\mathrm{a}}\right)$ (lower values) calculated from intact sediment cores and slurry samples in darkness (Figs. $6 \& 10$ ). $E_{\mathrm{a}} \pm \mathrm{SE}$ $\left(\mathrm{kJ} \mathrm{mol}^{-1}\right.$ ) is given below the $Q_{10}, \mathrm{n}$ is number of regression points

\begin{tabular}{|c|c|c|c|}
\hline & \multicolumn{3}{|c|}{ Nivå Bay Trondheimsfjord Adventfjord } \\
\hline \multicolumn{4}{|c|}{ Intact sediment core respiration } \\
\hline Prod. zone & $\begin{array}{c}3.5(\mathrm{n}=6) \\
80.5 \pm 19\end{array}$ & $\begin{array}{c}2.2(\mathrm{n}=12) \\
49.5 \pm 11\end{array}$ & $\begin{array}{c}3.5(\mathrm{n}=5) \\
81.4 \pm 20\end{array}$ \\
\hline Non-prod. zone & $\begin{array}{c}6.1(\mathrm{n}=6) \\
116 \pm 8.9\end{array}$ & $\begin{array}{c}2.4(\mathrm{n}=12) \\
56.1 \pm 11\end{array}$ & $\begin{array}{c}2.1(\mathrm{n}=5) \\
46.6 \pm 13\end{array}$ \\
\hline \multicolumn{4}{|c|}{ Slurred sample respiration } \\
\hline Prod. zone & - & $\begin{array}{c}1.9(\mathrm{n}=6) \\
42.0 \pm 10\end{array}$ & - \\
\hline Non-prod. zone & - & $\begin{array}{l}1.6(\mathrm{n}=5) \\
31.0 \pm 9.4\end{array}$ & - \\
\hline
\end{tabular}

$\mathrm{O}_{2}$-pd decreased with increasing temperature for all 3 sites (Fig. 9e), and calculated values of $Q_{10}$ were $0.78,0.82$ and 0.78 in Nivå Bay, the Trondheimsfjord and the Adventfjord, respectively (Table 3). Conclusively, $\mathrm{O}_{2}$-pd in the light showed a similar temperature response as in darkness but with $Q_{10}$ values closer to 1.0 .

The specific net photosynthesis $\left(P_{\mathrm{n}, \mathrm{vol}}\right)$ integrates the sum of the gross $\mathrm{O}_{2}$ production and the $\mathrm{O}_{2}$ consumption (in light) in the production zone. The $P_{\mathrm{n}, \mathrm{vol}}$ rates generally showed the same trend as $P_{\mathrm{n}}$ but with higher rates (Fig. 9f). The $Q_{10}$ of $P_{\mathrm{n} \text {,vol }}$ was $1.5,2.1$ and 1.6 for Nivå Bay, the Trondheimsfjord and the Adventfjord, respectively (Table 3), and there was no significant difference between the sites $(\mathrm{p}=0.34)$. The $P_{\mathrm{n}, \mathrm{vol}}$ data indicate that the temperature response of the production zone was similar to the entire oxic zone of the sediment exposed to light. 


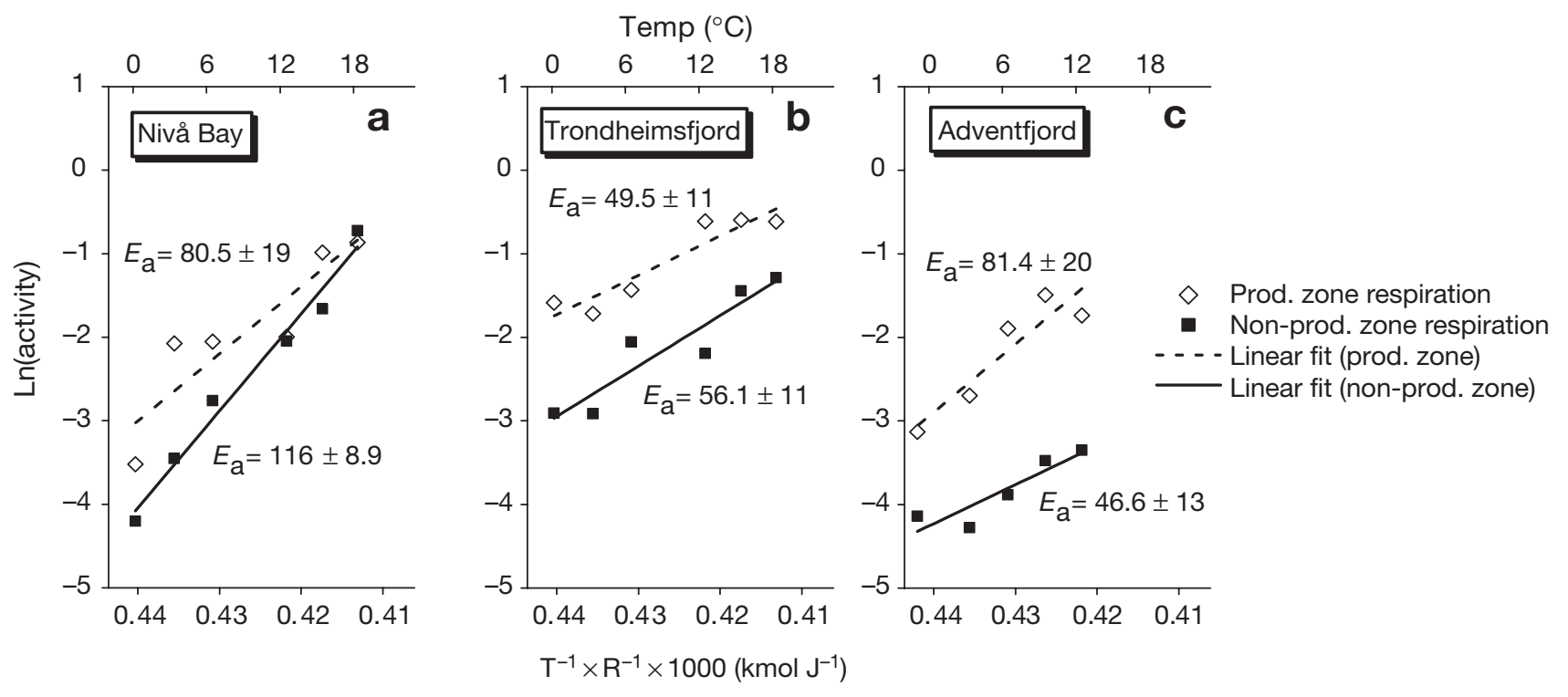

Fig. 6. Arrhenius plot of production and non-production zone. $\mathrm{O}_{2}$ consumption rates in darkness as function of temperature for (a) Nivå Bay, (b) the Trondheimsfjord and (c) the Adventfjord. Specific respiration rates for the separated zones are calculated from oxygen profiles. Lines represent linear fits and activation energies $\left(E_{\mathrm{a}}\right)$ are included. Corresponding $Q_{10}$ valuesare shown in Table 4

\section{Slurry experiments}

For the Trondheimsfjord, the oxygen consumption in darkness was additionally measured in sediment slurries from the oxic, production and non-production zones (Fig. 10). The experiment was performed partly to elucidate to what extent resuspension affects the biological response and to allow for comparison with previous studies of temperature effects on $\mathrm{O}_{2}$ consumption rates, which mainly have been conducted on slurred samples. Oxygen consumption of the entire oxic zone increased with temperature from $0^{\circ} \mathrm{C}$ to $T_{\text {opt }}$ at $21^{\circ} \mathrm{C}$ followed by a decrease, and $Q_{10}$ was $1.7 \pm 0.5$ (Fig. 10, Table 3). Oxygen consumption of the separated production and nonproduction zones showed similarly increasing rates with increasing temperature towards $T_{\text {opt }}$ at 24 and $39^{\circ} \mathrm{C}$, respectively (Fig. 10a). For both sediment zones, a clear decrease in the consumption rate was observed at temperatures higher than $T_{\text {opt }} \cdot Q_{10\left(6-16^{\circ} \mathrm{C}\right)}$ for the initial $\mathrm{O}_{2}$ consumption increase $\left(6\right.$ to $\left.18^{\circ} \mathrm{C}\right)$ was 1.9 and 1.6 for the production and non-production zones, respectively (Fig. 10b, Table 4). $Q_{10}$ of the sediment slurries showed a generally weaker temperature response than the $R_{\text {dark,vol }}$ rates for intact sediment cores. The higher $T_{\text {opt }}$ for the non-production than for the production zone indicates a higher temperature optimum for the heterotrophic community than for the phototrophic-dominated part of the sediment, presumably due to the overall vertical zonation of phototrophs and heterotrophs. The $Q_{10}$ value, however, was not significantly different for the 2 zones.

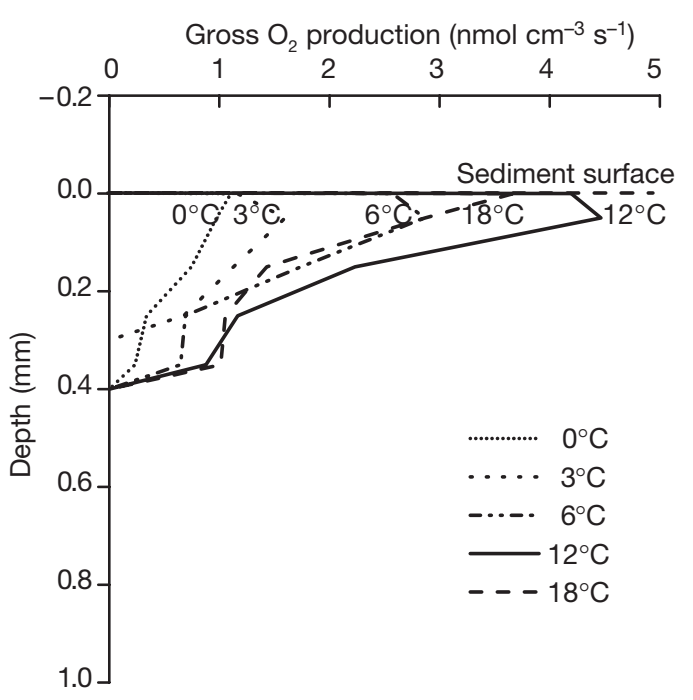

Fig. 7. Gross $\mathrm{O}_{2}$ production profiles as a function of temperature in the Trondheimsfjord. Areal rates of gross photosynthesis were calculated from the integrated area of each profile

(Fig. 8)

\section{DISCUSSION}

\section{Heterotrophic temperature response}

Despite differences in water temperature and geographical position, the $Q_{10}$ for the short-term temperature response of the dark respiration showed no signif- 

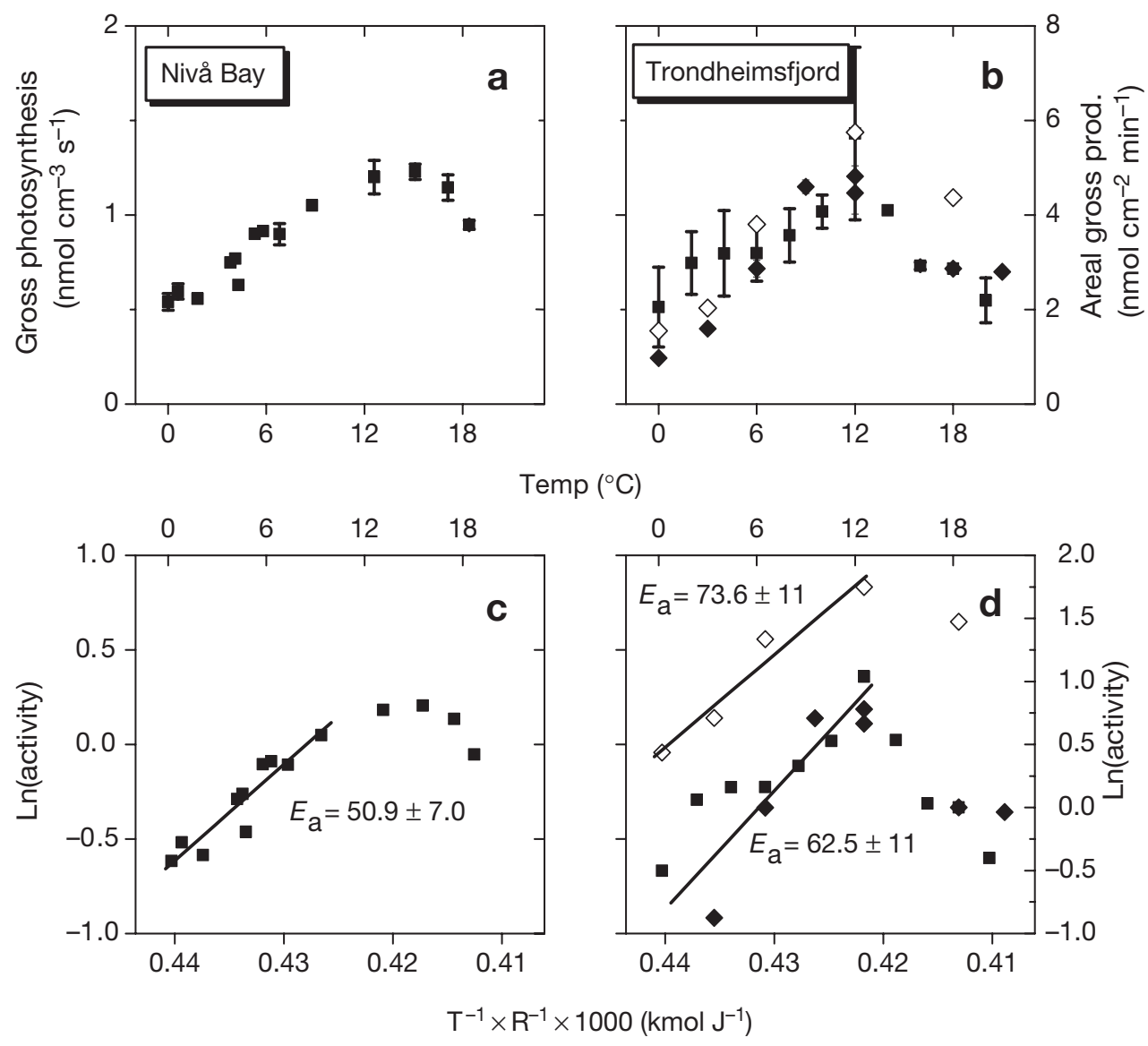

$\diamond P_{\text {gross }}$

- $P_{\text {gross,vol }}$

$P_{\text {gross }, \text { vol }}$

(separate data set divided by 4)

Fig. 8. Gross photosynthesis rates as a function of temperature in (a) Nivå Bay and (b) the Trondheimsfjord. Closed symbols indicate volumetric spot measurements, whereas open symbols represent depth-integrated areal gross photosynthesis rates (note different $y$-axis scales). $(\bullet)$ Separate data set obtained data divided by 4 . Arrhenius plots of the rates shown in (a) and (b) are presented in

(c) and (d), respectively. Activation energies $\left(E_{\mathrm{a}} \pm \mathrm{SE}_{;} \mathrm{kJ} \mathrm{mol}^{-1}\right)$ are included: corresponding $Q_{10}$ values are shown in Table 3

icant difference $(\mathrm{p}>0.05)$ between the 3 sites. This was true for both TOE and DOE rates, with one exception for TOE in Nivå Bay showing a higher $Q_{10}$ than for the 2 other sites $(\mathrm{p}<0.05)$; we have no good explanation for this exception. In general, we conclude that the temperature acclimation response was similar for the 3 investigated sites. The lack of any distinct latitude related temperature adaptation strategy could be due to the relatively moderate temperature difference between the investigated sites during sampling. In fact, the seasonal temperature amplitude at each site was larger than the temperature difference between the sites at the time of sampling (Table 1). Moreover, the diel temperature amplitude for the 2 temperate sites, in summer, exceeded the temperature difference between the 3 sites at sampling (in winter), with Nivå Bay demonstrating a diel temperature amplitude of up to $10^{\circ} \mathrm{C}$ during summer (data not shown). It can be speculated that a seasonal temperature acclimation at each site could be more pronounced than any latitude related response.
A comparative study on short-term temperature effects of aerobic respiration in slurred coastal sediments also concluded that Arctic and temperate sediments had similar $Q_{10}$ values (Thamdrup \& Fleischer 1998). However, a seasonal temperature acclimation was observed for the temperate site, with $Q_{10\left(0-10^{\circ} \mathrm{C}\right)}$ of 2.0 and 3.0 for winter $\left(1\right.$ to $3^{\circ} \mathrm{C}$ ) and summer (13 to $15^{\circ} \mathrm{C}$ ), respectively (Thamdrup et al. 1998). The seasonal $Q_{10}$ response was ascribed to a physiological acclimation or a change in the genotypic composition of the aerobic community. These findings contrast conclusions of sulphate reduction measurements, obtained in intact sediment incubations, having $Q_{10\left(2-12^{\circ} \mathrm{C}\right)}$ of 1.5 and 3.0 to 3.9 for Antarctic and temperate sediments, respectively (Isaksen \& Jørgensen 1996). However, $E_{\mathrm{a}}$ in the range of 40 to $75 \mathrm{~kJ} \mathrm{~mol}^{-1}$ (corresponding to a $Q_{10\left(0-10^{\circ} \mathrm{C}\right)}$ of 1.8 to 3.2$)$ for sulphate reduction have been published from the permanently cold areas around Svalbard (Sagemann et al. 1998), also pointing to a non-consistent latitude dependence of $Q_{10}$ on sulphate reduction rates. 
$Q_{10}$ for the area based dark heterotrophic response varied from 1.7 to 3.3. Published $Q_{10}$ values of areal $\mathrm{O}_{2}$ consumption rates from comparable experiments range between 2.0 and 3.0 for subtidal and intertidal sites (Duff \& Teal 1965, Davis \& McIntire 1983). A broader range of $Q_{10}$ values are published derived from correlations between seasonal rates and water temperatures and from manipulated samples (e.g. Grant 1986, Therkildsen \& Lomstein 1993). The latter findings are, however, not directly comparable to our short-term incubations.

$Q_{10}$ for TOE tended to be higher than for DOE. As previously mentioned, this supports a stronger temperature response for the heterotrophs compared to the phototrophs in the dark, as DOE is measured at spots with high biomass of phototrophs, compared to TOE integrating the entire core surface. TOE data potentially include the infauna response, which can lead to a relatively higher $Q_{10}$ due to infaunal respiration. $Q_{10}$ for fauna respiration is typically published to be $\sim 2.5$ and it cannot be excluded that it affected the $Q_{10}$ based on the TOE rates (Caron et al. 1990).

The $Q_{10}$ values for the specific rate $\left(R_{\mathrm{dark}, \text { vol }}\right)$ were higher than the area based values (2.6 to 5.2, Table 3 ). As previously described, the $R_{\text {dark, vol }}$ is corrected for the $\mathrm{O}_{2}$-pd and solely represents the microbial response, where the temperature effects on the areal rates are biased by the decreasing thickness of the oxic zone, with increasing temperature. In the literature, there are only very few measurements of benthic volumespecific temperature responses from similar settings and these were not performed on intact communities but on slurred samples. Our measurements show that the temperature response in slurred sediments is lower than in undisturbed sediment cores, with a $Q_{10}$ of 1.7 $\left(E_{\mathrm{a}}=35.7 \pm 9.3\right)$ versus $2.6\left(E_{\mathrm{a}}=61.8 \pm 10\right)$, respectively (Table 3). The lower temperature response following resuspension must be ascribed to a radical change in the community structure and the micro-environmental controls of the community. Our data show that $Q_{10}$

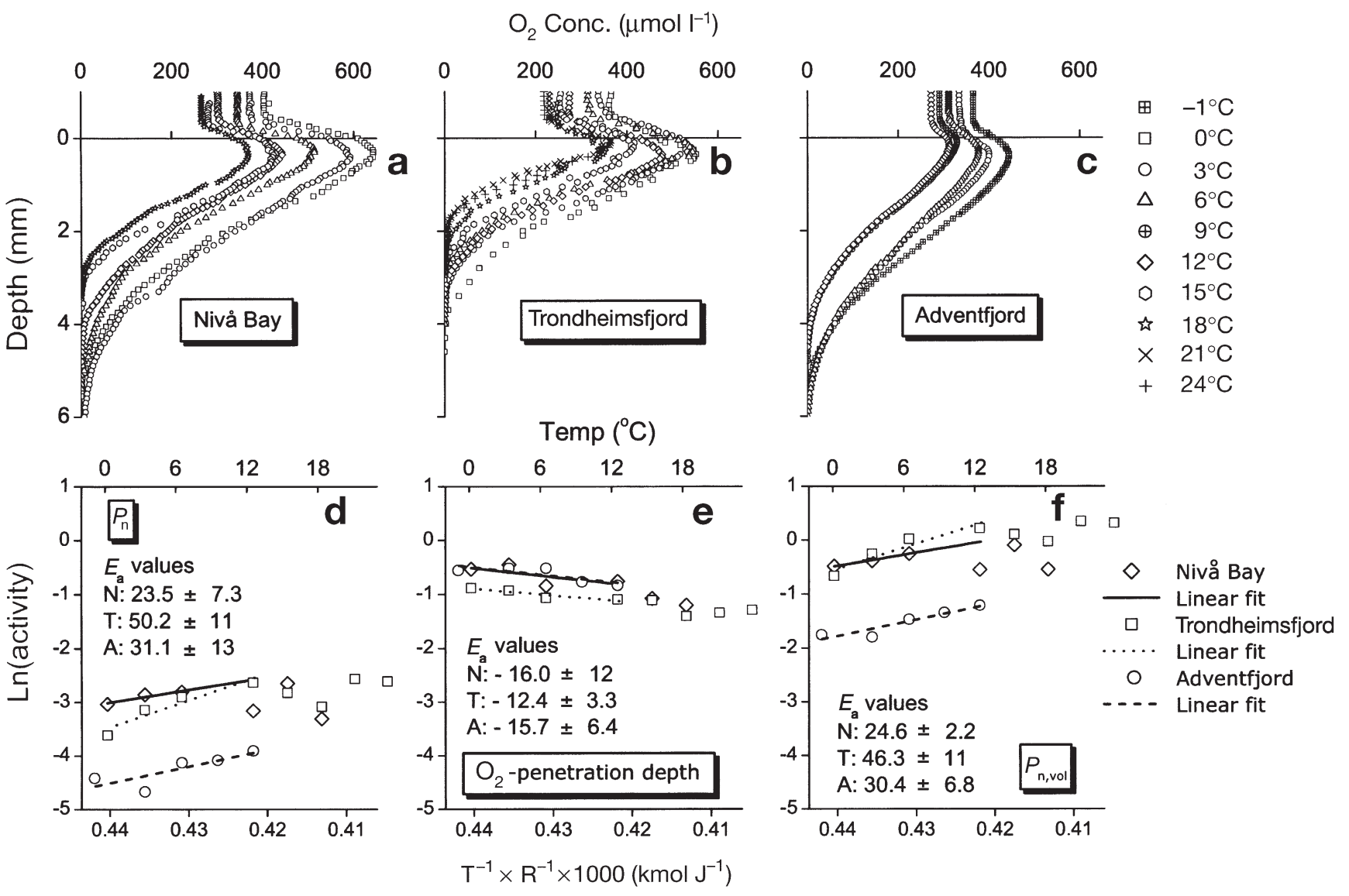

Fig. 9. Steady-state $\mathrm{O}_{2}$ microprofiles in intact sediment cores at $140 \mu \mathrm{mol}$ photons $\mathrm{m}^{-2} \mathrm{~s}^{-1}$ at various temperatures $\left(-1\right.$ to $\left.24^{\circ} \mathrm{C}\right)$ from (a) Nivå Bay, (b) the Trondheimsfjord and (c) the Adventfjord. Arrhenius plots of (d) diffusive oxygen exchange (DOE) equivalent to the areal net photosynthesis $\left(P_{\mathrm{n}}\right)$, (e) the oxygen penetration depth and (f) the specific net photosynthesis of the production zone $\left(P_{\mathrm{n}, \mathrm{vol}}\right)$ as a function of temperature are shown. Activation energies $\left(E_{\mathrm{a}} \pm \mathrm{SE}_{;} \mathrm{kJ}^{\mathrm{mol}}{ }^{-1}\right)$ are included, labelled N (Nivå Bay), T (Trondheimsfjord) and A (Adventfjord) (d-f). Corresponding $Q_{10}$ values are shown in Table 3 


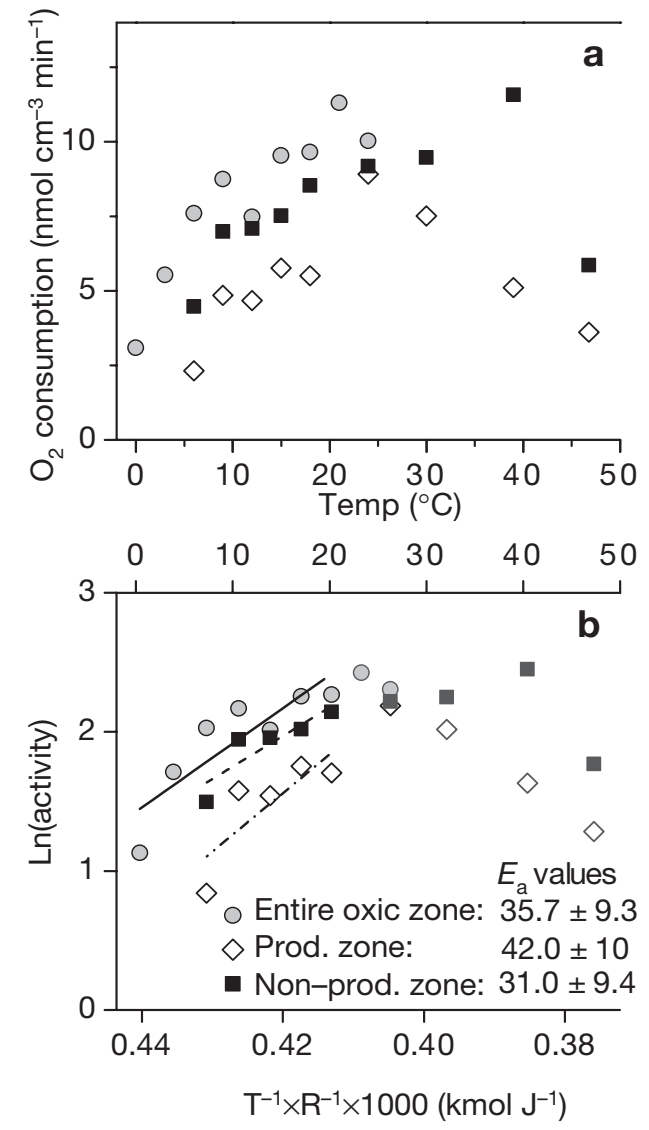

Fig. 10. (a) $\mathrm{O}_{2}$ consumption of sediment slurries in darkness from the Trondheimsfjord as a function of temperature. (b) Arrhenius plot of rates in (a). Data were fitted linearly in the temperature interval 0 to $18^{\circ} \mathrm{C}$ for the oxic zone and 6 to $18^{\circ} \mathrm{C}$ for the production and non-production zones, corresponding to available data. Activation energies $\left(E_{\mathrm{a}} \pm \mathrm{SE}\right.$; $\mathrm{kJ} \mathrm{mol}^{-1}$ ) are included (b). Corresponding $Q_{10}$ values are shown in Tables 3 \& 4

values from sediment $\mathrm{O}_{2}$ consumption studies, estimated from areal rates and slurred samples, generally underestimate the temperature response of intact sediment microbial communities.

\section{Phototrophic temperature response}

The temperature response of the gross photosynthesis from the 2 investigated sites was very similar (Table 3). At both sites, $P_{\text {gross }}$ and $P_{\text {gross, vol }}$ increased almost linearly until reaching $T_{\text {opt }}$ of 12 to $15^{\circ} \mathrm{C}$, whereafter it gradually decreased. The curve expresses a classical metabolic temperature response, thus the following criteria for cardinal temperatures were used for categorisation: for psychrophiles, $T_{\min }<0^{\circ} \mathrm{C}, T_{\text {opt }} \leq$ $15^{\circ} \mathrm{C}$ and $T_{\max } \leq 20^{\circ} \mathrm{C}$; for psychrotrophs, $T_{\min } \leq 0^{\circ} \mathrm{C}$, $T_{\text {opt }} \leq 25^{\circ} \mathrm{C}$ and $T_{\max } \leq 35^{\circ} \mathrm{C}$; and for mesophiles, $T_{\text {opt }}$ is $\sim 25$ to $40^{\circ} \mathrm{C}$ and $T_{\max } \approx 35$ to $45^{\circ} \mathrm{C}$ (Isaksen \& Jørgensen 1996). Even though cardinal temperature ranges traditionally refer to thermal classes of growth, with narrower limits and lower optimums, they have also been used to describe metabolic activity (Isaksen \& Jørgensen 1996, Thamdrup \& Fleischer 1998). This generally accepted scheme categorises the gross photosynthetic response for both Nivå Bay and the Trondheimsfjord as psychrotrophic. Studies from the Danish and Dutch Wadden Seas, applying other techniques, have shown lower-end mesophile temperature responses of gross photosynthesis, with $T_{\text {opt }}$ of 15 to $30^{\circ} \mathrm{C}$ (Colijn \& van Buurt 1975, Rasmussen et al. 1983, Blanchard et al. 1996).

In the literature, $Q_{10}$ values of benthic photosynthesis have been based on a variety of different laboratory and in situ techniques, which grossly hamper any direct comparison. The majority of published $Q_{10}$ values, however, are within the range of 1.5 to 2.5 (e.g. Colijn \& van Buurt 1975, Davis \& McIntire 1983, Grant 1986), with a few outliers representing air-exposed intertidal sediments (Rasmussen et al. 1983). In general, a $Q_{10}$ of $\sim 2$ for the gross photosynthetic rate is commonly accepted (Davison 1991). Our data are at the high end (2.2 to 3.1 ) of any comparable studies; however, all previous measurements were performed by ${ }^{14} \mathrm{C}$ incubation techniques, which are known to poorly represent the in situ rates (e.g. Revsbech et al. 1981). To our knowledge, no previous studies have compared the benthic temperature response of gross photosynthesis at different geographic settings.

Several intertidal studies have shown diatom migration on both diel and seasonal scales, and suggested temperature and light to be controlling factors (e.g. Barranguet et al. 1998, Saburova \& Polikarpov 2003). However, migration of diatoms (or physical mixing) can occur without any measurable effect on the overall photosynthetic activity of the benthic community (Blanchard \& Gall 1994). In the present study, the benthic activity distribution was unaffected by changes in temperature and the conclusions on activity changes were thus not confounded by any vertical migration. We can, however, not exclude the possibility that migration took place but had no effect on the overall activity distribution.

\section{Heterotroph versus phototroph temperature response}

The present study shows that increasing temperature stimulates the heterotrophic activity more than gross photosynthesis. Consequently, the typically mixed benthic community of heterotrophic and phototrophic microbes gradually turns heterotrophic at increasing temperature. A gradual transition from a phototrophic- to a heterotrophic-dominated community with increasing 
temperature has previously been reported for intertidal sediments, with $Q_{10}$ values of 2.05 and 2.70 for gross photosynthesis and respiration, respectively (Davis \& McIntire 1983). The authors hypothesize that a high $Q_{10}$ can be seen as a response to high water-temperature variability and, hence, the authors ascribe the higher $Q_{10}$ for the respiration to a more efficient acclimation of heterotrophic compared to phototrophic organisms. Similar observations have been made in temperate planktonic communities (Lefèvre et al. 1994, Robinson 2000) and for Antarctic macroalgae (Wiencke et al. 1993). The observations have generally been explained by a stronger and more rapid physiological acclimation of heterotrophic metabolism compared to photosynthesis during short-term temperature variations. In the present study, however, the diel temperature variability was low at the time of sampling and the data do not support the idea of a more rapid acclimation of heterotrophic metabolism. The stronger heterotrophic temperature response, as observed in this study, seems to be a general phenomenon rather than being exceptional. This was supported by Robinson (2000) with data from a pelagic study carried out in the relatively temperature-stable Aegean Sea.

A comparable detailed microsensor study on temperature responses of a cyanobacterial mats in Solar Lake (Egypt) (in situ temperatures of 25 to $45^{\circ} \mathrm{C}$ ) has been performed. The study indicated a relatively low temperature response of the $\mathrm{O}_{2}$ consumption in the dark (1.3) compared to the gross photosynthesis (3.1) (Wieland \& Kühl 2000). The authors ascribed the low $Q_{10}$ for respiration to a limitation of the $\mathrm{O}_{2}$ transport across the DBL at such high temperatures $\left(>40^{\circ} \mathrm{C}\right)$. However, the $Q_{10}$ values were calculated from areal rates and, hence, they do not represent the true microbial response. In accordance with our observations, the authors also concluded that at a moderate irradiance (as for the present study), temperature clearly increased the percentage of $\mathrm{O}_{2}$ which was consumed within the cyanobacterial mat. Thus, elevated temperature increased the light requirement for a net phototrophic community and, hence, at constant irradiance, the mat turned into a net heterotroph community at increasing temperature. Recalculating the data from Wieland \& Kühl (2000), correcting the areal rates for the $\mathrm{O}_{2}$-pd, led to a $Q_{10\left(25-35^{\circ} \mathrm{C}\right)}$ for the volume-specific $\mathrm{O}_{2}$ consumption of 2.7. This 2-fold higher $Q_{10}$ for the specific rate is in agreement with our study and supports that $Q_{10}$ values estimated from areal rates underestimate the microbial community temperature response.

All $Q_{10}$ values in the present study of $\mathrm{O}_{2}$ consumption were calculated from dark consumption rates. In light, phototrophic as well as heterotrophic organisms consume $\mathrm{O}_{2}$, and besides the metabolic respiration, elevated $\mathrm{O}_{2}$ consumption can be caused by photorespiration and the turn-over of excreted photosynthate by heterotrophic organisms. Several studies have documented a higher (10 to $30 \%$ ) $\mathrm{O}_{2}$ consumption in light compared to that in the dark, due to photorespiration and associated processes (Glud et al. 1992, 1999, Epping \& Jørgensen 1996, Wieland \& Kühl 2000). The present study does not allow for detailed calculation of $\mathrm{O}_{2}$ consumption in light, nor was it possible to calculate the $Q_{10}$ for the $\mathrm{O}_{2}$ consumption in light from the data of Wieland \& Kühl (2000).

In general, substrate limitation is not considered rate limiting in coastal shallow water sediments, as a net flux of nutrients and DOC from the sediment to the water column is typical (Dalsgaard 2003). However, due to the tight spatial and temporal coupling between production and consumption of organic matter (e.g. Epping \& Jørgensen 1996) and the light-dependent excretion of photosynthates by microphytes, it is possible that improved substrate availability will fuel an increased respiration in light. No sign of rate-suppressing substrate limitation was observed in the present study.

In conclusion, no difference in the temperature acclimation response between the sites was observed, suggesting that the temperature adaptation strategic for the benthic microbial community was the same for the arctic and the temperate community. The biological temperature response for the sediment $\mathrm{O}_{2}$ consumption, as derived from the volume-specific $\mathrm{O}_{2}$ consumption rate $\left(R_{\text {dark,vol }}\right)$ showed higher $Q_{10}$ values than derived from areal flux measurements. Thus, $Q_{10}$ calculated from areal rates of sediment $\mathrm{O}_{2}$ consumption will underestimate the $Q_{10}$ for the microbial temperature response. Similarly, we suggest that slurred sediment samples for estimation of metabolic activity and responses to changes of environmental factors, i.e. temperature or irradiance, will underestimate the response due to significantly altered microenvironments. The present study shows that increasing temperature stimulates heterotrophic activity more than gross photosynthesis, and consequently, the sediment gradually turns heterotrophic with increasing temperature.

Acknowledgements. O. J. Lønne and the staff at The University Centre on Svalbard (UNIS) are gratefully acknowledged for the help with logistics and providing field equipment and laboratory facilities. A. Glud deserves a special thanks for providing excellent microelectrodes and technical assistance. N. O. G. Jørgensen is greatly acknowledged for constructive criticism of the work. G. Johnsen, the staff at Trondheim Biological Station and the crew at Harry Borthen II are greatly thanked for their efforts in assisting the fieldwork in the Trondheimsfjord and at the Biological Station. T. Johansen and J. Evertsen provided indispensable assistance and a cheerful working climate during all diving operations. Finally, we thank 3 anonymous reviewers for constructive criticism that improved the manuscript. The research was supported by the Danish Natural Research Council and by the Improving Human Potential-Transnational Access to Research Infrastructures Programme of the European Commission. 


\section{LITERATURE CITED}

Barranguet CJ, Kromkamp J, Peene J (1998) Factors controlling primary production and photosynthetic characteristics of intertidal microphytobenthos. Mar Ecol Prog Ser 173:117-126

Berry JA, Bjorkman O (1980) Photosynthetic response and adaptation to temperature in higher-plants. Annu Rev Plant Physiol 31:491-543

Blanchard GF, Gall VC (1994) Photosynthetic characteristics of microphytobenthos in Marennes-Oléron Bay, France: preliminary results. J Exp Mar Biol Ecol 182:1-14

Blanchard GF, Guarini JM, Richard P, Gros P, Mornet F (1996) Quantifying the short-term temperature effect on lightsaturated photosynthesis on intertidal microphytobenthos. Mar Ecol Prog Ser 134:309-313

Broecker WS, Peng TH (1974) Gas exchange rates between air and sea. Tellus 26:21-35

Cahoon LB (1999) The role of benthic microalgae in neritic ecosystems. Oceanogr Mar Biol Annu Rev 37:47-86

Caron DA, Goldman JC, Fenchel T (1990) Protozoan respiration and metabolism. In: Capriulo GM (ed) Ecology of marine protozoa. Oxford University Press, New York, p 307-322

Colijn G, van Buurt G (1975) Influence of light and temperature on the photosynthetic rate of marine benthic diatoms. Mar Biol 31:209-214

Crank J (1989) The mathematics of diffusion. Clarendon Press, Oxford

Dalsgaard T (2003) Benthic primary production and nutrient cycling in sediments with benthic microalgae and transient accumulation of macroalgae. Limnol Oceanogr 48: 2138-2150

Davis MW, McIntire CD (1983) Effects of physical gradients on the production dynamics of sediment-associated algae. Mar Ecol Prog Ser 13:103-114

Davison IR (1991) Environmental effects on alga photosynthesis: temperature. J Phycol 27:2-8

Duff S, Teal JM (1965) Temperature change and gas exchange in Nova Scotia and Georgia salt-marsh muds. Limnol Oceanogr 10:67-73

Epping EHC, Jørgensen BB (1996) Light enhanced oxygen respiration in benthic phototrophic communities. Mar Ecol Prog Ser 139:193-203

Epping EHC, Kühl M (2000) The responses of photosynthesis and oxygen consumption to short-term changes in temperature and irradiance in a cyanobacterial mat (Ebro Delta, Spain). Environ Microbiol 2:465-474

Fenchel T, Glud RN (2000) Benthic primary production and $\mathrm{O}_{2}-\mathrm{CO}_{2}$ dynamics in a shallow-water sediment: spatial and temporal heterogeneity. Ophelia 53:159-171

Glud RN, Ramsing NB, Revsbech NP (1992) Photosynthesis and photosynthesis-coupled respiration in natural biofilms measured by use of oxygen microsensors. J Phycol 28: $51-60$

Glud RN, Jensen K, Revsbech NP (1995) Diffusivity in surficial sediments and benthic mats determined by use of a combined $\mathrm{N}_{2} \mathrm{O}-\mathrm{O}_{2}$ microsensor. Geochim Cosmochim Acta 59:231-237

Glud RN, Kühl M, Kohls O, Ramsing NB (1999) Heterogeneity of oxygen production and consumption in a photosynthetic microbial mat as studied by planar optodes. J Phycol 35:270-279

Glud RN, Gundersen JK, Ramsing NB (2000) Electrochemical and optical oxygen microsensors for in situ measurements. In: Buffle J, Horvai G (eds) In situ monitoring of aquatic systems - chemical analysis and speciation. J Wiley \& Sons, Chichester, p 19-75
Glud RN, Kühl M, Wenzhöfer F, Rysgaard S (2002) Benthic diatoms of a high arctic fjord (Young Sound NE Greenland): importance for ecosystem primary production. Mar Ecol Prog Ser 238:15-29

Grant J (1986) Sensitivity of benthic community respiration and primary production to changes in temperature and light. Mar Biol 90:299-306

Gundersen JK, Glud RN, Ramsing NB (1998) Predicting the signal of $\mathrm{O}_{2}$ microsensors from physical dimensions, salinity and $\mathrm{O}_{2}$ concentration. Limnol Oceanogr 43:1932-1937

Hartwig EO (1978) Factors affecting respiration and photosynthesis by the benthic community of a subtidal siliceous sediment. Mar Biol 46:283-293

Isaksen MF, Jørgensen BB (1996) Adaptation of psychrophilic and psychrotrophic sulfate-reducing bacteria to permanently cold marine sediments. Appl Environ Microbiol 62: 408-414

Jørgensen BB, Revsbech NP (1985) Diffusive boundary layers and the oxygen uptake of sediments and detritus. Limnol Oceanogr 30:111-122

Klinkenberg LJ (1951) Analogy between diffusion and electrical conductivity in porous rocks. Bull Geol Soc Am 62: 559-564

Kühl M, Jørgensen BB (1994) The light-field of microbenthic communities - radiance distribution and microscale optics of sandy coastal sediments. Limnol Oceanogr 39: 1368-1398

Kühl M, Glud RN, Ploug H, Ramsing NB (1996) Microenvironmental control of photosynthesis and photosynthesiscoupled respiration in an epilithic cyanobacterial biofilm. J Phycol 32:799-812

Lefèvre D, Bentley TL, Robinson C, Blight SP, Williams PJL (1994) The temperature response of gross and net community production and respiration in time-varying assemblages of temperate marine micro-plankton. J Exp Mar Biol Ecol 184:201-215

Li YH, Gregory S (1974) Diffusion of ions sea water and in deepsea sediments. Geochim Cosmochim Acta 38:703-714

MacIntyre HL, Cullen JJ (1995) Fine-scale vertical resolution of chlorophyll and photosynthetic parameters in shallowwater benthos. Mar Ecol Prog Ser 122:227-237

Parsons TR, Strickland JHD (1963) Discussion of spectrophotometric determination of marine-plant pigments with revised equations for ascertaining chlorophylls and carotenoids. J Mar Res 21:155-163

Rasmussen MB, Henriksen K, Jensen A (1983) Possible causes of temporal fluctuations in primary production of the microphytobenthos in the Danish Wadden Sea. Mar Biol 73:109-114

Raven JA, Geider RJ (1988) Temperature and algae growth. New Phycol 110:441-461

Revsbech NP (1989) An oxygen microelectrode with a guard cathode. Limnol Oceanogr 34:474-478

Revsbech NP, Jørgensen BB (1983) Photosynthesis of benthic microflora measured by the oxygen microprofile method: capabilities and limitations of the method. Limnol Oceanogr 28:749-56

Revsbech NP, Jørgensen BB (1986) Microelectrodes - their use in microbial ecology. Adv Microb Ecol 9:293-352

Revsbech NP, Jørgensen BB, Brix O (1981) Primary production of microalgae in sediments measured by oxygen microprofile, $\mathrm{H}^{14} \mathrm{CO}_{3}{ }^{-}$fixation, and oxygen exchange methods. Limnol Oceanogr 26:717-730

Revsbech NP, Madsen B, Jørgensen BB (1986) Oxygen production and consumption in sediments determined at high spatial resolution by computer simulation of oxygen microelectrode data. Limnol Oceanogr 31:293-304 
Robinson C (2000) Plankton gross production and respiration in the shallow water hydrothermal systems of Milos, Aegean Sea. J Plankton Res 22:887-906

Saburova MA, Polikarpov IG (2003) Diatom activity within soft sediments: behavioural and physiological processes. Mar Ecol Prog Ser 251:115-126

Sagemann J, Jørgensen BB, Greeff O (1998) Temperature dependence and rates of sulfate reduction in cold sediments of Svalbard, Arctic Ocean. Geomicrobiol J 15: $85-100$

Thamdrup B, Fleischer S (1998) Temperature dependence of oxygen respiration, nitrogen, mineralization, and nitrification in Arctic sediments. Aquat Microb Ecol 15: 191-199

Thamdrup B, Hansen JW, Jørgensen BB (1998) Temperature dependence of aerobic respiration in a coastal sediment.

Editorial responsibility: John Dolan,

Villefranche-sur-Mer, France
FEMS Microbiol Ecol 25:189-200

Therkildsen MS, Lomstein BA (1993) Seasonal-variation in net benthic C-mineralization in a shallow estuary. FEMS Microbiol Ecol 12:131-142

Ullmann WJ, Aller RC (1982) Diffusion coefficients in nearshore marine sediments. Limnol Oceanogr 27:552-556

Wieland A, Kühl M (2000) Irradiance and temperature regulation of oxygenic photosynthesis and $\mathrm{O}_{2}$ consumption in a hypersaline cyanobacterial mat (Solar Lake, Egypt). Mar Biol 137:71-85

Wiencke C, Rahmel J, Karsten U, Weykam G, Kirst GO (1993) Photosynthesis of marine macroalgae from Antarcticalight and temperature requirements. Bot Acta 106:78-87

Wintermans JFGM, DeMots A (1965) Spectrophotometric characteristics of chlorophylls $a$ and $b$ and their pheophytins in ethanol. Biochim Biophys Acta 109:448-453

Submitted: January 25, 2004; Accepted: August 23, 2004 Proofs received from author(s): November 5, 2004 